\title{
Estimating the Potential Impact of Requiring a Stand-Alone Board-Level Risk Committee
}

\section{Dissertation}

Presented in Partial Fulfillment of the Requirements for the Degree Doctor of Philosophy in the Graduate School of The Ohio State University

\author{
By \\ Michael Iselin \\ Graduate Program in Accounting and MIS \\ The Ohio State University \\ 2014 \\ Dissertation Committee: \\ Professor Anne Beatty, Advisor \\ Professor Darren Roulstone \\ Professor Douglas Schroeder \\ Professor Andrew Van Buskirk
}


Copyrighted by

Michael Iselin

2014 


\begin{abstract}
This paper investigates the effects of the requirement under the Dodd-Frank Act that all large bank holding companies create a stand-alone, board-level risk committee. In addressing this issue I focus on banks that had not voluntarily created such a committee prior to the legislation, as these are the banks that will be most affected by the new rule. I demonstrate an estimation method that makes it possible to draw inferences about the potential impact of a new rule before the rule is implemented. I find that requiring large banks to maintain a risk committee would have increased capital ratios during the global financial crisis, but would have decreased capital ratios during more stable economic conditions. The time varying nature of the results highlights the importance of estimating the effect of proposed policy changes over multiple states of the economy. This paper contributes to the literature by investigating the effects of a relatively understudied aspect of board structure, the presence of a risk committee, and by providing an identification strategy that can be used to investigate standard setting and regulatory changes before the changes are put in place.
\end{abstract}




\section{Acknowledgements}

I thank the members of my dissertation committee: Anne Beatty (Chair), Darren Roulstone, Doug

Schroeder and Andy Van Buskirk for helpful comments and continual support. I also thank Minkwan Ahn, Anil Arya, Sam Bonsall, Zahn Bozanic, Bret Johnson, Allison Nicoletti, Austin

Sudbury, Jennifer Stevens, and Xue Wang as well as workshop participants at The Ohio State

University, Georgetown University, University of Minnesota, University of Michigan, George

Washington University, University of Rochester, Purdue University, Florida State University and

University of Illinois-Chicago for helpful comments and suggestions. I gratefully acknowledge

financial support from the Deloitte Foundation Doctoral Fellowship and the Fisher College of

Business. 


\begin{tabular}{|c|c|}
\hline \multicolumn{2}{|c|}{ Vita } \\
\hline $2001 \ldots \ldots \ldots$ & James W. Robinson High School \\
\hline $2001-2005 \ldots$ & University of Notre Dame \\
\hline $2005-2007 \ldots$ & Tax Staff, Deloitte Tax \\
\hline $2007-2009$ & $\begin{array}{l}\text { Financial Analyst, Jones Lang } \\
\text { Lasalle }\end{array}$ \\
\hline 2009 - Present & $\begin{array}{l}\text { Graduate Research and Teaching } \\
\text { Assistant, Department of } \\
\text { Accounting and MIS, The Ohio } \\
\text { State University }\end{array}$ \\
\hline
\end{tabular}

Fields of Study

Major Field: Accounting and MIS 


\section{Table of Contents}

Abstract ...................................................... ii

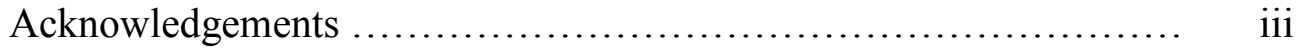

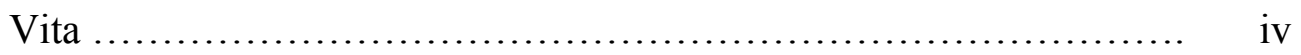

Table of Contents $\ldots \ldots \ldots \ldots \ldots \ldots \ldots \ldots \ldots \ldots \ldots \ldots \ldots \ldots \ldots \ldots \ldots \ldots \ldots \ldots, \quad \mathrm{v}$

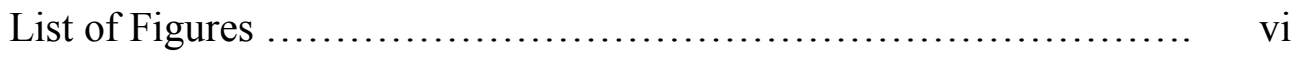

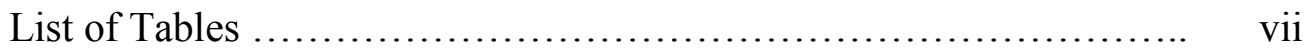

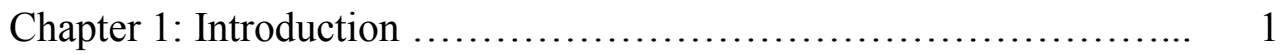

Chapter 2: Literature Review and Hypothesis Development ........... 8

Chapter 3: Data and Sample Selection $\ldots . \ldots \ldots \ldots \ldots \ldots \ldots \ldots \ldots \ldots \ldots . \quad 18$

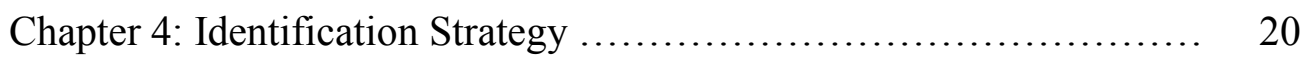

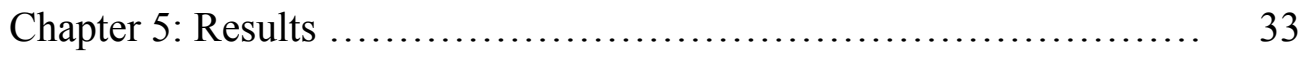

Chapter 6: Conclusion $\ldots \ldots \ldots \ldots \ldots \ldots \ldots \ldots \ldots \ldots \ldots \ldots \ldots \ldots \ldots \ldots, \quad 38$

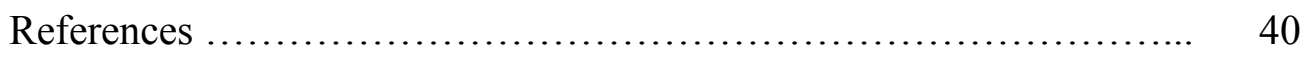

Appendix A: Variable Definitions ............................... 44

Appendix B: Numerical Example of Differences between Average Treatment on Treated and Average Treatment on Untreated ............. 45 


\section{List of Figures}

Figure 1: Distribution of Propensity Scores for ATUT Sample .............. 48

Figure 2: Interpretation of Regression Coefficients in Interaction Regression ............................................... 49

Figure 3: Distribution of Propensity Scores for ATT Sample .......... 50 


\section{List of Tables}

Table 1: Annual Breakdown of Risk Committee Creation and Existence .. 51

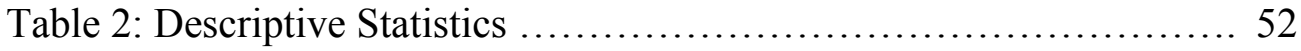

Table 3: Propensity Score Model .................................. 54

Table 4: Covariate Balance $\ldots . \ldots \ldots \ldots \ldots \ldots \ldots \ldots \ldots \ldots \ldots \ldots \ldots \ldots \ldots \ldots \ldots$

Table 5: The Effect of Risk Committee on Tier 1 Capital for Mandatory

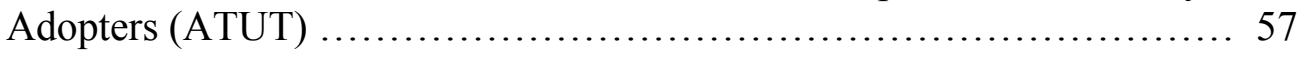

Table 6: The Effect of Risk Committee on Components of Tier 1 Capital Ratio for Mandatory Adopters ...................................... 59

Table 7: The Effect of Risk Committee on Tier 1 Capital for Voluntary

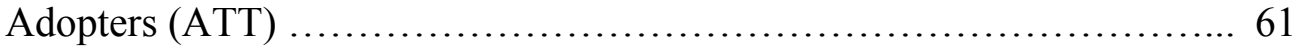




\section{Chapter 1: Introduction}

Following the recent global financial crisis, Congress passed the Dodd-Frank Wall Street Reform and Consumer Protection Act of 2010 ("Dodd-Frank Act" or "the Act”). On February 12, 2014 the Federal Reserve Board of Governors (FED) finalized the rule implementing Section 165 of the Act, which will require publicly traded bank holding companies with total assets greater than $\$ 10$ billion to create a stand-alone, board-level risk committee, distinct from the audit committee, prior to January $1,2015{ }^{1}$ This paper evaluates the effect on capital ratios of requiring a risk committee for those banks that have not voluntarily created such a committee prior to the legislation. In doing so, it demonstrates an identification technique that estimates the effect of a rule on mandatory adopters before they are required to adopt the rule.

Both Schipper (1994) and Fulbier et al. (2009) discuss the role that academic research can play in the accounting standard setting process and stress that policy relevant research should be ex ante in nature. However, they acknowledge that it is often difficult for archival studies to provide this ex ante evidence. Kachelmeier and King (2002) highlight this point, and argue for the use of experimental research to generate ex ante evidence with strong internal validity. Several papers attempt to provide ex ante evidence specifically to bank regulators by running simulations (Calem and Rob 1999; Furfine 2001; Estrella 2004; Gordy and Howells 2006). I contribute to this line of

\footnotetext{
${ }^{1}$ All references to a risk committee in this paper refer to a board-level risk committee that is separate from the audit committee unless stated otherwise.
} 
literature by highlighting circumstances under which empirical, archival research can provide ex ante evidence with policy implications. These circumstances include the presence of voluntary adopters of a rule, a strong set of covariates that help satisfy the identifying assumption, and some degree of similarity across voluntary and mandatory adopters. Given these characteristics, I provide one method to estimate the effect on mandatory adopters before the rule is implemented.

A second issue that I address is the importance of recognizing that the effects of policies can vary with changes in macroeconomic conditions. History shows that changes in regulation in general, and accounting standard setting specifically, tend to come in waves following periods of economic turmoil (Waymire and Basu 2007; Watts and Zimmerman 1979; Romano 2005; Dewatripont et al. 2010). As examples, the stock market crash of 1929 and the great depression led to the Securities Acts; the savings and loan crisis of the 1980s led to the Financial Institutions Reform, Recovery and Enforcement Act of 1989, the accounting scandals of the early 2000s led to the SarbanesOxley Act; and recently the global financial crisis led to the Dodd-Frank Act. Although the new rules policy makers put in place in response to crises are intended to resolve the current crisis and avoid future problems, these rules generally remain in effect during more stable economic conditions. Therefore, when examining the potential impact of a new rule, it is important to view the rule through a longer term lens, and specifically ask whether or not the effects of the rule differ depending on the state of the economy. I highlight this point by providing evidence that requiring a risk committee can lead to different effects on capital ratios depending on the economic conditions of the banking industry. 
I find that requiring banks to have a stand-alone risk committee during the financial crisis would have led to an increase in capital ratios. The magnitude of this effect is a 1.16 percentage point increase in Tier 1 capital ratios, which is economically significant, representing an $8.2 \%$ increase for the average firm. ${ }^{2}$ Creating a separate risk committee on the board of directors and delegating risk management to a group that can exclusively focus on that task results in higher capital ratios during volatile economic conditions.

Results before the crisis contrast with those during the crisis, and demonstrate the importance of estimating policy effects over differing economic conditions. I find that forcing banks to have a risk committee prior to the crisis would have led them to operate closer to the regulatory capital minimum. The estimated effect of requiring a risk committee during this time period is a reduction of the Tier 1 capital ratio by 0.9 percentage points. This result, coupled with the finding that risk committees increase capital ratios during the crisis, indicates that the effects of requiring a risk committee vary with the economic conditions.

These results suggest that requiring a stand-alone risk committee improves the quality of risk management at the board level and interacts with the economic conditions faced by the bank to yield different outcomes with respect to capital ratios. As economic conditions improve, boards with strong risk management functions can more easily and quickly shift from a policy requiring a larger capital buffer to one in which they increase the risk of the asset portfolio in an effort to increase returns. This shift will generate a

\footnotetext{
${ }^{2}$ To be "well capitalized" under current federal bank regulatory agency definitions, a bank holding company must have a Tier 1 capital ratio of at least $6 \%$.
} 
reduction in the capital buffer relative to what is observed during more volatile periods, and a decrease in the observed Tier 1 capital ratio.

This paper investigates the potential effect of mandating that all large banks create a risk committee. In addressing this question, it is important to recognize that banks that have a risk committee in place prior to the legislation are already in compliance with the new rule, and thus are largely unaffected by its implementation. ${ }^{3}$ Therefore, I argue that the subpopulation of interest in this study is the banks that do not already have a risk committee. A difficulty in estimating the effect on these banks to provide ex ante evidence of the potential impact of the rule is that I cannot observe changes in those banks after implementation of the rule because the rule has yet to be enacted.

The strategy I employ to estimate this effect begins with a matching approach. There are several covariates included in the matching process; therefore, I estimate a propensity score model to arrive at a single value on which I match a risk committee firm to each non-risk committee firm (Rosenbaum and Rubin 1983). This model estimates the presence of a risk committee as a function of several observable covariates. However, instead of selecting propensity scores at random following Rosenbaum and Rubin (1983) to estimate the overall average effect, or finding a match from the non-adopter sample for each voluntary adopter (Armstrong et al. 2010), I match each non-adopter (future mandatory adopter) to the voluntary adopter with the closest propensity score. These matched firms serve as the estimate of what capital ratios would have been for the future mandatory adopters if they had a risk committee in place. Although this matching

\footnotetext{
${ }^{3}$ There may be a minimal effect on these banks because the rule will prevent them from dissolving their risk committee at some point in the future, and also might require the bank to restructure the responsibilities delegated to the risk committee. I do not include either of these effects in my analysis.
} 
procedure sounds quite similar to standard propensity score matching techniques, it can result in different samples and will likely result in drawing inferences from different regions of the distribution of propensity scores. Inferences about voluntary adopters are more likely to come from the upper range of the propensity score, whereas inferences about mandatory adopters are more likely to come from the lower range of the propensity score.

The key identifying assumption I rely on is conditional mean independence (CMI). Identification strategies employing this assumption are not new to the literature. These strategies include propensity score methods, matching estimators, and regression discontinuity designs. CMI is fundamentally untestable, but by relying on this assumption and providing some intuition as to why it might be satisfied I am able to draw stronger inferences from my results. I discuss CMI in more detail in Chapter 4. A second criterion necessary to identify effects in this setting is an area of common support, or overlap, among the covariates for the mandatory adopters and the matched voluntary adopters. It is only over this region, where the two groups are similar, that appropriate inferences can be drawn from the data.

An additional requirement of the Dodd-Frank Act and the rule finalized by the FED is that each risk committee must be chaired by an outside director and must include at least one director with risk management expertise. I attempt to further validate my findings by only including those banks that meet both of these conditions as potential matches for the non-risk committee sample. The definition of risk management expertise provided in the rule is quite vague. To operationalize this requirement I consider a board member to be a risk management expert if he or she has served as an executive at either a 
bank or an insurance company. Imposing this additional requirement strengthens the magnitude and statistical significance of the results during both time periods, suggesting that these additional requirements will be beneficial in maximizing the impact of the regulation.

To help further understand the impact of requiring a risk committee I investigate whether the changes in Tier 1 capital ratios that I document are primarily driven by the numerator or the denominator of the ratio. Most of the risk associated with running a large bank comes from the different assets that the bank holds. Additionally, unlike manufacturing firms, the assets of a bank are all relatively liquid and the riskiness of the asset portfolio of a bank can be altered rather quickly. Consistent with risk coming from the asset side of the balance sheet, I find that the effects of a risk committee are concentrated in changes to risk weighted assets of the bank in both the pre-crisis and the crisis periods.

This paper contributes to the corporate governance and banking literatures. I examine the potential regulatory effects of a relatively understudied aspect of the board of directors, the presence of a stand-alone risk committee. I provide evidence that requiring banks to have a stand-alone board-level risk committee is likely to increase capital ratios during times of crisis when the threat of systemic failure is at its peak. However, I also find that the presence of a risk committee results in banks decreasing their capital ratios during stable economic conditions. My evidence that the impact of this specific governance mechanism is conditional on the economic conditions faced by the industry should be of interest to both regulators and academics because it highlights 
the importance of allowing for the possibility that other governance related effects may also be time varying in nature.

I also make two methodological contributions that are broadly applicable to research interested in providing evidence to policy makers or accounting standard setters. First, I illustrate an identification strategy that, under certain circumstances, allows archival research to provide ex ante evidence that informs the standard setting process. I provide an example of when this method is useful and how to implement it empirically by examining the requirement under the Dodd-Frank Act that large banks create a risk committee on their board of directors. Second, I highlight the importance of estimating the effect of new regulations over multiple time periods. I document that the direction of the effect of creating a risk committee on capital ratios differs depending on the state of the economy.

The remainder of the paper proceeds as follows. Chapter 2 presents a literature review and develops the hypotheses. Chapter 3 discusses the data and sample selection. I explain my identification strategy in Chapter 4 and present results in Chapter 5. Finally, Chapter 6 concludes the paper. 


\section{Chapter 2: Literature Review and Hypothesis Development}

\subsection{Literature Review}

The Dodd-Frank Act is a direct consequence of the global financial crisis and includes several provisions that will potentially change the structure of bank governance systems. Gao et al. (2013) examine stock and bond market responses to key events leading to the passage of the Dodd-Frank Act. Their results suggest that markets did not expect the final version of the bill to reduce risk taking at large financial institutions. This paper differs from Gao et al. (2013) in that instead of addressing the Dodd-Frank Act as a whole, I focus on the single requirement that banks form a stand-alone, boardlevel risk committee. While this more narrow focus limits my ability to draw conclusions about the overall impact of the Act, it allows me to draw more direct inferences about the potential influence of this particular rule.

The finance and accounting literature examining the role of the board of directors as a governance mechanism largely agrees that boards serve two primary functions; to monitor and advise management. Much of this work examines the monitoring role of the board as this function serves to mitigate the agency problem created by the separation of ownership and control (Beasley 1996; Anderson et al. 2004; Karamanou and Vafeas 2005; Ahmed and Duellman 2007). There are a few papers that investigate the advising role of the board and find that there are instances where directors are retained primarily to advise management (Agrawal and Knoeber 2001; Helland and Sykuta 2004). There are 
also papers that survey actual directors (Demb and Neubauer 1992; Adams 2009). Responses to these questionnaires suggest that a majority of directors believe their primary responsibility is to advise management and set the strategic objectives of the firm.

Adams et al. (2010) point out that most of the work that boards do happens within committees. Klein (1998) provides evidence to support that claim in the finding that overall director composition is unrelated to performance, but the proportion of inside directors on the investment and finance committees is positively related to performance. More specifically related to this paper, three recent studies incorporate the existence of a board-level risk committee into their analysis. Minton et al. (2014) are primarily interested in the effect of financial expertise on bank value during the crisis. They include the presence of a stand-alone risk committee as a control variable and find no evidence that having a risk committee impacts stock performance, change in firm value, or return volatility during the crisis. Aebi et al. (2012) find that banks with a board-level risk committee experienced lower buy-and-hold returns and return on equity during the crisis period, but if those committees met more often the negative impact was mitigated. Finally, Ellul \& Yerramilli (2013) construct a risk management index, one component of which is the presence of a board-level risk committee. In constructing this index, they do not differentiate between a stand-alone risk committee and a joint audit and risk committee. They find that banks with a stronger risk management function heading into the financial crisis experienced lower tail risk, lower non-performing loans and better operating and stock return performance during the crisis. 
This study differs from these papers in three important ways. First, I concentrate on the potential impact of the pending requirement that large bank holding companies create a stand-alone board-level risk committee. This focus leads me to investigate the effect of requiring those banks that do not have a risk committee in place to create one. I make this design choice because it is specifically these banks that will be affected by the risk committee requirement in the Dodd-Frank Act. Second, because this requirement is being imposed by regulators who are concerned with the bank's ability to meet its obligations, I focus on a measure of risk that is intended to capture the regulators' perspective as opposed to market based measures of risk. Third, I investigate the effect of a board-level risk committee not only during the crisis but also prior to the onset of the crisis.

\subsection{Outcome Measures}

A difficulty in providing research that is relevant in the accounting standard setting process is identifying a measurable outcome variable that captures the objectives of standard setters. Prior research relies on the FASB Concept Statements and operationalizes the constructs of relevance and faithful representation, but there is a lack of consensus regarding the applicability of these proxies (Barth et al. 2001; Holthausen and Watts 2001). I circumvent this issue by examining the effect of a bank regulation and relying on minimum regulatory capital ratios as a policy relevant outcome measure.

The banking industry is characterized by high levels of government regulation. In the United States the Federal Reserve Board of Governors (FED), the Office of the Comptroller of Currency (OCC) and the Federal Deposit Insurance Corporation (FDIC) oversee different aspects of bank regulation. Banks serve the important role in capital 
markets of aggregating the capital of risk averse depositors and deploying it to fund risky loans (Diamond and Rajan 2001; Diamond and Dybvig 1983). The objective of bank regulation is to minimize the risk of a failure in the banking industry. This objective closely mirrors the stated aim of the Dodd-Frank Act which is "To promote the financial stability of the United States by improving accountability and transparency in the financial system." Historically, regulators have sought to achieve this objective through regulation at the individual bank level. ${ }^{4}$

A primary mechanism that regulators use to meet this objective is to require that banks maintain a minimum Tier 1 capital ratio in hopes that the capital will be sufficient to absorb unexpected losses and keep the bank solvent (Kim and Santomero 1988). To be considered "well capitalized" a bank must maintain a Tier 1 capital ratio greater than $6 \%$ at all times. The numerator of the ratio is Tier 1 capital, which consists of common equity, perpetual preferred stock, minority interests and mandatory convertible instruments. Increases in the numerator increase the bank's ability to absorb unexpected losses. The denominator is risk weighted assets. Riskier assets receive a higher weight, whereas less risky assets receive a lower weight. As a bank decides to hold more risky assets the denominator of the Tier 1 capital ratio increases and the bank is forced to increase the amount of its Tier 1 capital in order to maintain the required ratio. The heavy reliance on the Tier 1 capital ratio by regulators leads me to focus on this ratio as the outcome variable of interest in this study.

\footnotetext{
${ }^{4}$ The second Basel Accord did include some provisions for a more macro approach to bank regulation, however, only the largest seven or eight banks in the US were subject to the Basel II rules and none of these banks are in my sample because they were all voluntary risk committee adopters. For a measure of systemic risk in the banking industry see Bushman \& Williams (2014).
} 
It is possible for bank regulators to respond to the recent financial crisis by simply increasing the minimum requirement for the Tier 1 capital ratio, without the need to require a risk committee or take any other indirect actions. While the Basel Committee on Banking Supervision is indeed proposing increases to the regulatory minimums, I argue that looking at the effect of other rules on capital ratios is also important. Holding capital is costly for banks (Diamond and Rajan 2000) and some banks are better able to manage their capital ratio than others. The presence of a risk committee is one mechanism that might allow for cross sectional variation in bank capital ratios that is preferred to simply requiring all banks to maintain much higher ratios.

Firms can impact their Tier 1 capital ratio by taking actions that affect either the numerator or the denominator of the ratio. To gain a deeper understanding of the mechanism(s) through which risk committees impact TIER1 I examine these two components separately. I investigate the numerator using total Tier 1 capital divided by total assets (CAPITAL) and the denominator using risk weighted assets divided by total assets (RWAT).

\subsection{Hypothesis Development}

Management must administer day-to-day risk management activities, but even prior to the Dodd-Frank Act, state laws and stock exchange requirements also hold boards accountable for risk oversight. Delaware law compels directors to implement and oversee a reporting system designed to inform them of material risks. ${ }^{5}$ NYSE listing

\footnotetext{
${ }^{5}$ In Re: Caremark International Inc. Derivative Litigation, 698 A.2d 959 (Del. Ch. 1996); Stone v. Ritter, 911 A.2d 362 (Del. 2006)
} 
status requires that the audit committee discuss policies regarding risk management. ${ }^{6}$ These rules place risk management responsibilities in the hands of the board, but neither of them require a stand-alone, board-level risk committee.

Boards often delegate risk management duties to the audit committee, and several even refer to that committee as the "Audit and Risk Committee." The Dodd-Frank Act will require all large bank holding companies to transfer that duty to a stand-alone risk committee. This paper considers whether shifting this responsibility from the audit committee or the full board to a separate committee, whose sole responsibility is risk management oversight, is likely to impact the capital ratios of affected banks.

Even if the audit committee is also responsible for risk management, the committee's primary role is to monitor the compilation of the financial statements and oversee the external audit. Banks that have voluntarily created risk committees delegate some or all of the following responsibilities, which will also be required of risk committees under the Dodd-Frank Act, to that committee: 1) review and approve policies associated with credit risk, market risk, liquidity risk, interest rate risk, compliance risk, legal risk, operational risk, or strategic risk; 2) meet regularly both with and without the presence of top management; 3) identify key risk metrics with which to evaluate the bank's position; 4) review major customer and lending relationships; and 5) review results of stress testing. It is possible for an audit committee to fulfill these responsibilities while also overseeing the external audit. However, delegating these

\footnotetext{
${ }^{6}$ NYSE Listed Company Manual $\S 303 A .07(b)(i i i)(D)$ and related commentary. The requirement allows a separate board-level committee to undertake these responsibilities as long as the risk oversight processes established by that committee are reviewed by the audit committee. The requirement is to discuss the guidelines and policies that govern risk management including, but not limited to, discussing the company's major financial risk exposures and steps management has taken to monitor and control such exposures.
} 
responsibilities to a separate committee is likely to result in additional time and resources being allocated to risk management.

Because the primary responsibility of the audit committee is to oversee the external audit and there is limited meeting time available for the audit committee to undertake this task, audit committee members may not have the time required to diligently fulfill their risk management responsibilities. Audit committee members are often high ranking employees at their own firms and have a limited amount of attention to devote to their role on the audit committee. This limited attention may lead them to brush off the secondary risk management duties in favor of focusing on the primary task of overseeing the external audit. Delegating the risk management function to a separate board-level committee likely mitigates both the time and attention constraints faced by those charged with risk management responsibilities and allows for more effective boardlevel risk management.

On the other hand, banks that will be affected by the new rule have already delegated these responsibilities either to the full board or the audit committee and have made the choice not to create a separate risk committee. This decision may indicate that the party currently responsible for board-level risk management is performing adequately, in which case compelling these firms to create a risk committee will not affect the board's risk management performance. The requirement to maintain a risk committee is a direct result of the volatile economic conditions faced during the recent global financial crisis. Therefore, my first hypothesis relates to the effect of requiring a risk committee during the crisis, and I state it in the null as follows: 
$\mathrm{H}_{1}$ : Requiring large bank holding companies to maintain a stand-alone risk committee on their boards of directors will have no effect on the capital ratios of these banks during volatile economic conditions.

The requirement to create and maintain a risk committee applies equally to times of crisis and periods of stable economic conditions. Therefore, understanding the full impact of the proposed rule also requires investigation of the consequences of having a risk committee outside of crisis periods. Adams (2009) states that "in times of normalcy, directors spend much more time as a sounding board for management and advising management on the strategic direction of the firm." As the economic conditions become less volatile, a board with a stronger risk management function may shift its focus from minimizing risk in an effort to ensure the future solvency of the bank to one of taking more calculated risks in an effort to increase the expected return of the asset portfolio. This shift in focus of a well performing risk committee may reduce the target capital ratio of the bank in less volatile conditions. The additional time and resources allocated to risk management through the creation of a risk committee might increase the likelihood that the bank employs a flexible target capital ratio.

Even if all banks shift their target capital ratio with the overall economic conditions, the presence of a risk committee might improve the ability of the bank to implement policy changes to hit the new target. Either of these scenarios would lead to observable differences in the effect of the risk committee on regulatory capital ratios in stable economic conditions relative to more tumultuous periods. The potential for differing effects on regulatory capital do not imply that a risk committee leads to suboptimal outcomes in one of the time periods. Rather, the presence of a risk committee improves board level risk management, but improved risk management leads to different 
predictions on the effect on regulatory capital ratios in different economic conditions. Therefore, I explore the effect of requiring a risk committee in non-crisis periods in the second hypothesis, also stated in the null:

$\mathrm{H}_{2}$ : Requiring large bank holding companies to maintain a stand-alone risk committee on their boards of directors will have no effect on the capital ratios of these banks during normal economic conditions.

Next, I investigate the mechanisms through which a risk committee might impact the Tier 1 capital ratio. Conditional on finding that the risk committee has an effect on this ratio, that effect might transpire either through a change in the numerator or the denominator of the ratio. The ratio is calculated as the banks' core equity capital divided by risk weighted assets. A straightforward way to increase the numerator is to issue new equity. Similarly, the numerator can be decreased by purchasing treasury stock or paying out dividends. If the risk committee uses these capital management strategies to affect the Tier 1 capital ratio then I expect the effect to be driven by the numerator.

The risk that a bank carries largely comes from the different type and quality of assets on its balance sheet. Therefore, the committee devoted to risk management might be more likely to monitor the Tier 1 capital ratio and advise changes to that ratio by setting policies that affect the denominator, risk weighted assets. Importantly, actions that affect risk weighted assets are much easier for a bank to take relative to an industrial firm because of the liquid nature of a bank's balance sheet. These actions might include monitoring the bank's loan portfolio and asset mix, approving changes to the loan policy, or prohibiting certain off balance sheet transactions. Because the denominator of the Tier 1 capital ratio is where the assessment of risk is made I hypothesize that a well 
performing risk committee is more likely to affect the Tier 1 capital ratio through the denominator than the numerator and explore these effects in the following hypotheses:

$\mathrm{H}_{3 \mathrm{~A}}$ : The presence of a stand-alone risk committee on the board of directors will have no effect on the numerator of the Tier 1 capital ratio.

$\mathrm{H}_{3 \mathrm{~B}}$ : The presence of a stand-alone risk committee on the board of directors will result in changes to the denominator of the Tier 1 capital ratio, risk weighted assets. 


\section{Chapter 3: Data and Sample Selection}

\subsection{Sample Selection and Risk Committee Variables}

The risk committee requirement in Section 165 of the Dodd-Frank Act only applies to public bank holding companies with total assets greater than $\$ 10$ billion. Because my focus is on those banks that will be affected by the Act, I restrict my sample to all public bank holding companies that have total assets greater than $\$ 10$ billion at the end of any quarter between 2004 and 2010. There are 69 unique banks that meet this threshold in the beginning of the sample period and 54 at the end of the sample period. However, based on either market capitalization or total assets, these banks represent more than 90 percent of all publicly traded bank holding companies that file FR Y9-C with the Federal Reserve in December 2010.

I identify the voluntary creation of a risk committee by performing key word searches of Proxy Statements and 10-Ks using both the Direct Edgar ISYS Query tool and Morningstar Document Research. I search for the words "risk" and "committee" within four words of one another. ${ }^{7}$ I then read through the filings and verify that the excerpts identified actually refer to a stand-alone risk committee as opposed to an audit and risk committee or use of the words "risk" and "committee" together for some other reason. If a stand-alone risk committee is present in a given bank year observation, I code the variable RC equal to 1 otherwise RC equals 0 .

\footnotetext{
${ }^{7}$ Examples of the naming convention for the risk committee on some boards include the following: Risk Committee, Risk Policy Committee, Risk Management Committee, Risk and Compliance Committee.
} 
One concern with this setting might be that the audit committee is comprised of the same members as the risk committee and there is no substantial change in the behavior, only in the naming and creation of a second committee. To mitigate this concern I collect the proportion of the risk committee members that also serve on the audit committee and find that an average of only 1 of 5 directors who sits on the risk committee also sits on the audit committee. This evidence suggests that the risk committees in my sample are distinct from the audit committee. ${ }^{8}$

Table 1 displays the annual breakdown of the banks that make up the sample. This table indicates that nine banks created a risk committee prior to 2004 and $33 \%$ of the sample banks have a risk committee in place by the end of 2007. By the end of the sample period in 2010 that number grows to almost $60 \%$. The table also shows that the number of large banks decreases over the years, and at the end of 2010 there are 54 banks with over $\$ 10$ billion in assets.

Table 2 provides descriptive statistics of all variables included in this study. Panel A provides distributional statistics and Panel B provides correlations. Panel A shows that $36 \%$ of bank-quarter observations come from those banks that have a risk committee. The mean TIER 1 is $11.00 \%$ and even at the $10^{\text {th }}$ percentile $(8.21 \%)$ banks still remain well above regulatory minimums. Panel B confirms the results of prior studies that TIER1 is negatively related to SIZE and also shows a small negative correlation between TIER1 and RC.

\footnotetext{
${ }^{8}$ There is only one firm where the risk committee is made up entirely of members from the audit committee. Results are robust to excluding that firm from the sample.
} 


\section{Chapter 4: Identification Strategy}

\subsection{Average Treatment Effect on the Untreated}

In an effort to identify the effect of interest and provide ex ante, policy relevant evidence about the potential impact of requiring large banks to create a risk committee on the board of directors, I draw on the econometrics literature that discusses treatment effects (Imbens and Angrist 1994; Heckman 1997; Hahn 1998; Greene 2008; Schroeder 2010; Wooldridge 2011). A treatment effect is defined as the difference between the outcome for a firm (or individual) with treatment and the outcome for that same firm, at the same time, without treatment. In practice we only ever observe one of these two outcomes, depending on whether or not a given firm received treatment. The other outcome is referred to as the counterfactual, and is fundamentally unobservable (i.e. what outcome would have been for a firm that did not receive treatment had they instead received treatment). The unobserved nature of counterfactuals makes it impossible to identify firm level treatment effects and leads to a focus on average treatment effects within a sample. The literature discusses several different treatment effects, but largely focuses on the average treatment effect (ATE) and the average treatment effect on the treated (ATT).

The ATE is the average treatment effect for the entire sample, whereas the ATT is the average treatment effect for the group of firms that receive treatment. I define treatment as implementation of a policy (presence of a risk committee) that has been 
voluntarily adopted by some firms. ${ }^{9}$ Given this definition the ATT represents the treatment effect on the voluntary adopters. Following the econometrics literature, and motivated by the research questions explored, most empirical estimation strategies identify either the ATE or the ATT (Tucker 2010). I argue that a third treatment effect, the average treatment effect on the untreated (ATUT), is the effect of interest in this paper given the empirical setting and the framing of the research question. ATUT is the average treatment effect for the group of individuals who did not receive treatment. It is specifically this population that will be affected and required to adopt treatment when regulators enact the risk committee rule. ${ }^{10}$

Estimation of the ATUT requires an estimate of what outcome would be in the presence of treatment for those firms that did not receive treatment. This is a similar problem faced by researchers attempting to identify the ATT, except they require an estimate of what outcome would be absent treatment for those firms that did receive treatment. This similarity leads me to employ a matched sample research design, which has been used by numerous papers in both accounting and economics (Rosenbaum and Rubin 1983; Armstrong et al. 2010; DeHaan et al. 2013). Implementation of this method requires three conditions to be met of the research setting. First, the policy or standard under question must have been voluntarily adopted by a subset of the population. These

\footnotetext{
${ }^{9}$ I distinguish between voluntary adopters and early mandatory adopters. Voluntary adopters are those firms that voluntarily adopt a policy without any belief that the policy will be mandated in the future. Early adopters, often seen in response to accounting standard changes, are those firms that adopt a policy before they are required to, but after a rule has already been passed that will require them to adopt the policy in the near future. I contend that voluntary adopters are unaffected by the rule whereas early mandatory adopters are affected by the rule.

${ }^{10}$ Appendix B provides a hypothetical, numerical example of differences between the effect on mandatory and voluntary adopters.
} 
voluntary adopters will be used to generate estimates of the counterfactual outcomes for the group of interest, those firms that have not voluntarily adopted the standard.

Second, there must be a set of control variables, $\mathrm{X}$, such that conditional mean independence is satisfied for outcome with treatment. This assumption is referred to in the accounting and econometrics literature by many names including, "selection on observables," "ignorable treatment," and "unconfoundedness." To more clearly state this condition, let $\mathrm{Y}_{1}$ denote hypothetical outcome if the firm receives treatment, $\mathrm{Y}_{0}$ denote hypothetical outcome if the firm does not receive treatment, and $\mathrm{D}$ be a dummy equal to 1 for firms with treatment and 0 for firms without treatment. Note that for any given firm-quarter observation only $Y_{1}$ or $Y_{0}$ is observed, depending on the value of $D$. The other outcome is a counterfactual and is unobservable. Given this setup, conditional mean independence for outcome with treatment is expressed as follows: ${ }^{11}$

$$
E\left[Y_{1} \mid X, D=0\right]=E\left[Y_{1} \mid X, D=1\right]=E\left[Y_{1} \mid X\right]
$$

Notice this assumption does not imply that observed outcome is independent of treatment. The first expression in Equation (1) is a counterfactual; outcome with treatment is never observed for firms that do not receive treatment. What this condition does require is that if two hypothetical firms that have the same value along all dimensions of $X$, then they have the same expected outcome in the presence of treatment regardless of whether they actually receive treatment.

Equations (2) thru (4) below formally present how this condition is relied upon in developing an estimate of ATUT. Equation (2) expresses the treatment effect of interest.

\footnotetext{
${ }^{11}$ Estimating the ATUT requires CMI for outcome with treatment. Estimating the ATT requires CMI to hold for outcome without treatment. Estimating the ATE requires CMI to hold for both outcome with and without treatment.
} 


$$
A T U T=E\left[Y_{1}-Y_{0} \mid D=0\right]=E\left[Y_{1} \mid D=0\right]-E\left[Y_{0} \mid D=0\right]
$$

By iterating expectations and conditioning on observable covariates this can be rewritten as:

$$
A T U T=E_{X}\left(E\left[Y_{1} \mid X, D=0\right]-E\left[Y_{0} \mid X, D=0\right]\right)
$$

I then add and subtract $E\left[Y_{1} \mid X, D=1\right]$ to the right hand side of equation (3):

$$
A T U T=E_{X}\left(E\left[Y_{1} \mid X, D=1\right]-E\left[Y_{0} \mid X, D=0\right]+E\left[Y_{1} \mid X, D=0\right]-\right.
$$

$E Y 1 / X, D=1$

The first two terms in Equation (4) represent observable quantities that can be estimated. The last two terms represent the estimation bias. It is clear that finding a vector $\mathrm{X}$ that satisfies conditional mean independence implies that the estimation bias equals zero. With this condition satisfied, Equation (4) reduces to two components that are both observable, which allows estimation of the effect of interest.

The third criterion necessary to draw appropriate inferences is a region of common support among the treated and untreated populations. This means that there must be both treated observations and untreated observations that have similar values of $\mathrm{X}$. It is only over the region of $\mathrm{X}$ where there is common support that valid inferences can be drawn from the available data. In a propensity score model, the argument for common support can be strengthened by only drawing inferences over the range of propensity scores with a non-zero density for both treated and untreated firms (Caliendo and Kopeinig 2008).

I argue that my setting meets these three conditions. Clearly there is a group of voluntary adopters, and I am able to identify them via disclosures made in proxy 
statements and 10Ks. I make the case that there is a set of control variables that can be relied on in this setting to satisfy conditional mean independence and discuss those variables in more detail in the next subsection. I also find that after estimating the propensity score model, there is a range of common support over which appropriate inferences can be drawn.

The unique aspect of my research design, relative to other uses of matched sample designs is the matching process. My interest in the treatment effect on mandatory adopters leads me to invert the standard matching process. Instead of matching each treatment firm with the most similar control firm, I do the opposite. I match each nonrisk committee firm with a risk committee firm in the same year that is most similar along the dimensions of X. I rely on the conditional mean independence assumption and use these matched risk committee firms to generate an estimate of the counterfactual outcome needed to estimate the effect of interest.

\subsection{Arguments for Conditional Mean Independence}

As stated previously, the identification strategy relies on finding a set of covariates that help satisfy conditional mean independence for outcome with treatment. This list of covariates should include any variable that is associated with both the presence of a risk committee and with the hypothetical Tier 1 capital ratio for each bank if they have a risk committee in place. I place these covariates into two categories based on how they affect the bank's Tier 1 capital ratio in the presence of a risk committee.

The first category contains those variables that affect what I call the inherent risk of the bank. Inherent risk refers to the nature and complexity of the bank's transactions, the risk appetite of the bank, and the quality of assets the bank holds. This inherent risk 
affects both the extent and ease with which a risk committee can manage regulatory risk. The second category contains those variables that affect what I call the risk management expertise of the potential risk committee. Risk management expertise refers to the abilities and experiences of potential members of the risk committee and affects the capability of a risk committee to impact regulatory risk if a risk committee is formed. I argue that this risk management expertise may be present to varying degrees at both banks with and without a risk committee, and that the expertise has an impact on regulatory risk only if it is put to use on a risk committee.

Variables that I hypothesize affect outcome with treatment through inherent risk include the following. First, lagged Tier 1 capital ratio (TIER1) is included to control for both the time series correlation in TIER1 as well as the strong time series correlation in the presence of a risk committee. Larger, more complex banks might be more likely to employ a risk committee and also tend to operate at lower capital ratios. I include the log of total assets (SIZE) to control for this size effect. Banks with more volatile operations are likely to need a larger buffer above the regulatory minimum capital ratio and also may require closer monitoring of their risk management at the board-level. To control for this volatility effect, I include idiosyncratic return volatility (IDIOVOL) measured as the standard deviation of residuals from a regression of daily stock returns over the prior quarter on the value weighted market index. I also include the market beta estimated from this regression (BETA) as a measure of the bank's sensitivity to overall market risk. Total cash scaled by total assets (CASH) controls for liquidity risk and also has an impact on the risk weighted assets, as cash is assigned a zero risk weight by regulators. I control for the risk inherent in trading and securitization activity of the bank by including total 
trading assets scaled by total assets (TRADING) and total securitized assets scaled by total assets (SECURITIZED). Banks that engage in these activities may institute greater board-level monitoring of risk management by creating a risk committee. I include a time trend variable (TIME) to control for the trend in the presence of risk committees. This variable takes the value of 1 for observations in 2004, 2 for observations in 2005 and so on.

Several of the variables I include in the model may affect both inherent risk and risk management expertise. I include book to market ratio (BTM) as younger, growth firms may be both less likely to have formed a risk committee and more susceptible to volatility in their capital ratio. I control for the percentage of institutional ownership (INSTOWN) as institutional owners may be able to exert control over both the presence of a risk committee and the target capital ratio. I control for asset quality with both the loan loss reserve scaled by total assets (LLR) and nonperforming loans scaled by total loans (NPL) as asset risk is a major concern for banks and a direct determinant of the denominator of the Tier 1 capital ratio, risk weighted assets. Additionally, banks with a riskier loan portfolio may require increased risk management oversight at the board level in the form of a risk committee. I include return on assets (ROA) as a measure of bank performance. A well performing bank may be less likely to necessitate the creation of a risk committee, and earnings directly affect the numerator of the Tier 1 capital ratio.

Finally, I include four board variables that are hand collected from the proxy statements that capture additional facets of the board's risk management expertise. The number of directors that sit on the board (BDSIZE) captures the depth of talent and experiences available to draw upon in creating a risk committee. The percentage of 
directors that are independent (BDINDEP) captures the breadth of those skills and experiences and together with BDSIZE controls for the availability of talent on the board from which to create a risk committee. The number of full board meetings held in a given year (BDMEET) captures the amount of time that board members of a given bank dedicate to oversight of that bank. Lastly, if the CEO also serves as chairman of the board (CEOCHAIR), she will have some control over both the presence of a risk committee and the makeup of that committee.

One variable that is missing from this list is the presence of a risk committee on the board in the previous period. I exclude this variable for two reasons. First, I fully acknowledge that the presence of a risk committee last year definitely plays a role in whether a risk committee is present this year. However, I argue that conditional on all the other covariates that I have discussed in this section, the presence of a risk committee last period is unlikely to impact TIER1 this period in the presence of a risk committee. The second reason that I exclude the lagged presence of a risk committee from the propensity score regression relates to implementation difficulties. Because the lagged presence of a risk committee is so highly correlated with the presence of a risk committee in the current period, I am unable to obtain satisfatory matches from the propensity score matching procedure to draw appropriate inferences.

\subsection{Propensity Score Model}

The large number of covariates discussed above makes direct matching infeasible. To address this dimensionality issue, I employ propensity score matching (Heckman et al 1998; Rosenbaum and Rubin 1983; Armstrong et al. 2010). I estimate the likelihood that each bank has a risk committee in the year of interest as a function of lagged values of the 
previously described control variables. Although I estimate the propensity score model as a determinants model, the purpose of this step is not to model the determinants of the decision to utilize a risk committee. ${ }^{12}$ Instead, the goal of the propensity score model is to generate good matches for the non-risk committee firms such that an argument can be made that conditional mean independence is satisfied for the final sample.

I estimate the propensity score using only data from the fourth quarter of every year, when proxy statements that identify the presence of a risk committee are available. I estimate the following pooled logistic regression:

$$
\begin{aligned}
& R C_{i, t}=\delta_{0}+\delta_{1} \text { TIER }_{i, t-1}+\delta_{2} \text { SIZE }_{i, t-1}+\delta_{3} \text { IDIOVOL }_{i, t-1}+\delta_{4} \text { BETA }_{i, t-1}+ \\
& \delta_{5} \text { CASH }_{i, t-1}+\delta_{6} \text { TRADING }_{i, t-1}+\delta_{7} \text { SECURITIZED }_{i, t-1}+\delta_{8} \text { BTM M }_{i, t-1}+ \\
& \delta_{9} \text { INSTOWN }_{i, t-1}+\delta_{10} \text { LLR }_{i, t-1}+\delta_{11} \text { NPL L }_{i, t-1}+\delta_{12} \text { ROA }_{i, t-1}+ \\
& \delta_{13} \text { BDSIZE }_{i, t-1}+\delta_{14} \text { BDINDEP }_{i, t-1}+\delta_{15} \text { BDMEET }_{i, t-1}+ \\
& \delta_{16} \text { CEOCHAIR }_{i, t-1}+\text { TIME }_{t}+\varepsilon_{i, t}
\end{aligned}
$$

From this regression I use the predicted probability of having a risk committee as the propensity score. Before I implement the matching procedure I identify the minimum propensity score for the risk committee firms, and the maximum propensity score from the non-risk committee firms. I then discard any observations for which the propensity score falls outside this range to ensure that I draw inferences over the range of common support of the propensity score (Caliendo and Kopeinig 2008). ${ }^{13}$ Then for each non-risk committee firm, I find the treatment firm with the smallest absolute difference in

\footnotetext{
${ }^{12}$ To highlight this point, imagine in the extreme that the propensity score model perfectly predicted the presence of a risk committee. In this case it would be impossible to find any reasonable matches because the densities of the treated and untreated firms would all be at 1 and 0 respectively.

${ }^{13}$ Excluding bank-quarter observations that fall outside the range of common support eliminates observations from 6 banks that do not have a risk committee. Results are robust to including observations outside the common support region, however, including these observations requires extrapolating beyond the available data and may threaten the validity of inferences.
} 
propensity score in the same year and use this risk committee firm as the match for the four quarters of the following year. To improve the quality of the matches I allow the matched firm to change each year. I match with replacement to decrease the bias from the resulting estimator at the expense of increasing the variance of that estimator because the distribution of propensity scores across treated and untreated firms are quite different (Smith and Todd 2005).

Table 3 provides results of the propensity score regression. The results indicate that larger banks with higher book to market ratios are more likely to have a risk committee. Additionally, the current composition of the board plays a role in the presence of a risk committee. Boards with a greater percentage of independent directors are more likely to have a risk committee.

Table 4 presents one method of assessing the covariate balance between the nonrisk committee firms and the matched risk committee firms. I follow Wooldridge (2011) and Imbens and Rubin (2012) and evaluate the overlap by computing the normalized differences. For each variable, $\mathrm{X}$, as well as the estimated propensity score the normalized difference is calculated as:

$$
\frac{\left(\bar{X}_{1}-\bar{X}_{0}\right)}{\left(s_{1}^{2}+s_{0}^{2}\right)^{1 / 2}}
$$

Where $\bar{X}_{g}$ is the sample average of $\mathrm{X}$ for group $\mathrm{g}=\mathrm{RC}$, and $s_{g}$ is the corresponding sample standard deviation. Wooldridge (2011) and Imbens and Rubin (2012) suggest that absolute normalized differences greater than 0.25 are cause for concern. Table 4 Panel A shows that after matching on the propensity score using all risk committee firms as potential matches, only one of the seventeen variables have normalized differences 
greater than the suggested 0.25 benchmark. Table 4 Panel B presents the normalized differences for the sample that requires a risk committee firm to have both a risk expert and an outside director serving as chair of the committee for the firm to be included as a potential match. Imposing this restriction lowers the quality of the matches. Four of the seventeen variables have normalized differences greater than the 0.25 benchmark in this sample. $^{14}$

As an alternative assessment of covariate balance, I also examine the distribution of propensity scores across the treated and untreated groups. Figure 1 Panel A presents the distribution for the two groups before performing the propensity score matching. As expected, the untreated observations are clustered at the low end of the range and the treated observations are concentrated at the higher end of the range. Figure 1 Panel B shows the two distributions after the matching procedures are implemented and reveals a much stronger overlap in the propensity scores across the two groups. This evidence not only provides comfort that the two subsamples are similar along the observable control variables, but also indicates that there is a region of support in the propensity scores over which I can draw appropriate inferences.

\subsection{State Contingent Treatment Effects}

The financial crisis represents a shock to the riskiness of several classes of bank assets. Banks' exposure to the assets affected by this increase in risk was a key trigger of the crisis (Kashyap et al. 2008; Acharya and Richardson 2009; Skeel 2011). Congress

\footnotetext{
${ }^{14}$ Additionally, as a robustness test I require the difference in propensity scores between $\mathrm{RC}$ and non-RC firms to be within $25 \%$ of the propensity score of the non-RC firm. This restriction improves the quality of the matches at the expense of a smaller sample size. All results are qualitatively unchanged in this smaller sample providing evidence that the inferences drawn from the main sample are appropriate.
} 
passed the Dodd-Frank Act as a direct response to the crisis. For this reason, I estimate the ATUT during the crisis to determine whether the presence of a risk committee affects capital ratios during that volatile time period. However, the risk committee requirement will be in place during both volatile and stable periods in the future, so it is also important to estimate the effect in the presence of stable economic conditions. To estimate both of these effects, I include a dummy variable for the crisis period (CRISIS) in the model as well as an interaction between the CRISIS and RC. I also include the full set of controls from the propensity score regression with the exception of lagged TIER1 to further control for any residual differences between risk committee and non-risk committee firms after the matching procedure. The model is presented below in Equation (7):

$\operatorname{TIER}_{i, t}=\alpha+\beta_{1} R C_{i, t}+\beta_{2} \operatorname{CRISIS}_{t}+\beta_{3} \operatorname{CRISIS}_{t} \times R C_{i, t}+\sum \gamma_{k} \operatorname{CTRLS}+\varepsilon_{i, t}$

I include observations from the three years before the onset of the crisis (2004, 2005 and 2006) as well as the three years after the onset of the crisis $(2008,2009$ and 2010). The variable CRISIS takes a value of 1 for all observations during and after the crisis $(2008,2009$ and 2010) and 0 for all observations prior to the crisis $(2004,2005$ and 2006). ${ }^{15}$ As illustrated in Figure 2, under the identifying assumption of conditional mean independence, $\beta_{1}$ captures the treatment effect of interest in the pre-crisis period. The sum $\beta_{1}+\beta_{3}$ captures the treatment effect of interest in the crisis period. $\beta_{3}$ alone captures the change in the treatment effect from the pre-crisis period to the crisis period. If the presence of a risk committee at those banks that did not have a risk committee would

\footnotetext{
${ }^{15}$ I exclude 2007 from the analysis as I am unable to determine at what point during the year firms created a risk committee and thus cannot accurately classify them as having or not having a risk committee in July 2007 at the onset of the crisis. Inferences remain unchanged if instead I denote July 2007 as the beginning of the crisis and include observations from 2007. Standard errors are clustered by firm (Petersen 2009).
} 
have affected capital ratios in the pre-crisis period, then I expect an estimate of $\beta_{1}$ that is significantly different from zero. Similarly, an estimate of $\beta_{1}+\beta_{3}$ that is significantly different from zero will provide evidence of an effect of the presence of a risk committee during the crisis. Finally, if the effect of having a risk committee changes from the precrisis period to the crisis period then I expect a significant coefficient estimate for $\beta_{3}$. 


\section{Chapter 5: Results}

\subsection{Main Results}

Table 5 presents the results of the main regressions with TIER1 as the dependent variable. Columns (1) and (2) present the results of the sample without restrictions on the matched risk committee firms. The coefficient on $\mathrm{RC}$ is negative and significant suggesting that having a risk committee would have led the non-risk committee firms to have a lower Tier 1 capital ratio in the pre-crisis period. The coefficient estimate on the interaction term $\mathrm{RC}^{*} \mathrm{CRISIS}$ is positive and significant. Panel B presents an F-test of the significance of $\beta_{1}+\beta_{3}$. This test reveals that during the crisis period the presence of a risk committee would have increased Tier 1 capital ratios. This evidence suggests that the effect of having a risk committee in place is different depending on the overall state of the economy. Specifically, the effect is to decrease capital ratios in the pre-crisis period and to increase them during the crisis.

Columns (3) and (4) present the results for the sample restricting the matched risk committee firms to have a risk expert on the committee and an outside director serving as chair of the committee. Qualitatively the results for this sample are no different from the prior sample. However, the magnitude of the estimated effects increases in both the precrisis and the crisis period and the coefficient estimates are also more statistically significant. These findings suggest that the requirement that risk committees include a 
risk expert and an outside director as chair is likely to magnify the effects of the risk committee requirement relative to what might be expected without these provisions.

The economic magnitude of these effects is also significant. Results from Column (1) (Column (3)) indicate that banks without a risk committee would have had a lower Tier 1 capital ratio by $0.90(1.26)$ percentage points which represents a decrease of $8.2 \%(11.6 \%)$ for the average non-risk committee firm. The effect increased at the onset of the crisis by 2.06 (3.78) percentage points. The net effect in the crisis period was an increase in TIER1 of 1.16 (2.52) percentage points which represents an increase of $10.7 \%$ (23.1\%) for the average non-risk committee firm.

After documenting these effects, I proceed to test $\mathrm{H}_{3 \mathrm{~A}}$ and $\mathrm{H}_{3 \mathrm{~B}}$ and separately examine the numerator and denominator of the Tier 1 capital ratio. Table 6 presents the results of these two regressions in columns (1) through (4). Columns (1) and (2) yield no evidence that either the effect in the pre-crisis period or the crisis period is driven by equity management. Columns (3) and (4) provide support for $\mathrm{H}_{3 \mathrm{~B}}$ and document evidence that the effect in both time periods are attributable to changes in the risk weighted assets. This finding is consistent with the risk committee playing a role in the supervision and approval of the bank's asset management policy.

\subsection{Average Treatment Effect on the Treated}

To provide a comparison to the main results obtained by estimating the effect on the mandatory adopters, this subsection presents results of the effect on voluntary adopters. To generate these estimates, I use the same propensity score model, but instead of finding the best match among the risk committee firms for each non-risk committee firm the matching process is reversed. I still restrict the sample to the range of common 
support but now find the non-risk committee firm in the same year that has the smallest absolute difference in propensity score for each risk committee firm. I again match with replacement to improve the quality of the matches, and the process results in a different sample than the one used for the main tests. To highlight this point Figure 3 presents the distribution of propensity scores for this sample. As can be seen from comparing Figure 3 to Figure 1 Panel B, the propensity scores of the observations used to draw inferences about the ATT are higher on average than those used to draw inferences about the ATUT. The reason for this pattern is that the firms of interest when estimating the ATT are the firms that chose to have a risk committee. If the propensity score model explains the variation in the treatment choice these firms should have higher predicted values (propensity scores) from the propensity score regression than firms that chose not to have a risk committee in place.

It is important to point out that identifying ATT relies on a different identifying assumption than what is required to identify ATUT. Estimation of ATT requires conditional mean independence for outcome without treatment. This is the case because when estimating the effect on the population of treated firms, outcome with treatment is observable, it is outcome without treatment that needs to be estimated. Just because conditional mean independence for outcome with treatment is satisfied does not imply that conditional mean independence for outcome without treatment is satisfied.

With this caveat in mind, Table 7 presents the results of estimating Equation (7) on this new sample of firms. This estimation of the ATT yields coefficients on the main variables of interest ( $\mathrm{RC}$ and $\left.\mathrm{RC} \mathrm{C}^{*} \mathrm{CRISIS}\right)$ that are both smaller in magnitude than the estimate of ATUT and also statistically insignificant. These differences highlight the 
importance of estimating the effect on the appropriate population. Drawing inferences from estimating ATT alone in this setting might lead to the conclusion that there is no significant effect of the presence of a risk committee. Estimating the ATUT to answer the question of what the potential impact of requiring all large banks to create and maintain a risk committee uncovers potential effects of the rule that would not be identified by only estimating the ATT.

There are at least two potential reasons why there would be no effect on capital ratios for the banks that voluntarily created a risk committee, but a positive effect on banks that will be required to do so. First, this analysis largely abstracts away from any costs associated with creating a risk committee. It may be the case that the decision to create a stand-alone risk committee is driven more by the costs of doing so. In this case we observe banks with low costs but also potentially little or no benefits creating standalone risk committees, while banks with more significant costs and potentially also significant benefits choosing not to create a risk committee. A second potential reason is that the outcome variable of interest in this study, Tier 1 capital ratio, is primarily intended to capture the utility of the bank regulators, not the individual banks or boards of directors who make the decision to voluntarily adopt a risk committee. While it is true that banks care about and pay attention to their capital ratio, there are also other metrics that are included in their performance assessment. It may be the case that the presence of a risk committee does not have a large impact on voluntary adopters regarding capital ratios, but does impact those banks in other ways that are important to them.

\subsection{Robustness Tests}


I perform several robustness tests to ensure that the inferences that I draw regarding the average treatment effect on the untreated firms are appropriate. First, Caliendo and Kopeinig (2008) point out that including extraneous variables in the propensity score model may both exacerbate the support problem and increase the variance of estimators. To address this concern, I replicate the main analysis including only those variables that are statistically significant in the propensity score model (SIZE, IDIOVOL, BTM, BDINDEP). The results remain qualitatively unchanged.

Another concern is whether the presence of a risk committee is correlated with management level risk management. I have attempted to control for the overall risk management of the firm by including measures of asset quality, return volatility, and earnings. However, in robustness tests, I also include combinations of the governance index from Gompers et al. (2003), the risk management index from Ellul and Yerramilli (2013), the tenure of the CEO, and the percentage of the CEO's compensation package comprised of equity based pay in both the propensity score model and the main regression. Each of these variables is only available for a subset of my sample. Additionally, the governance index is only available prior to 2006, so I use the 2006 value for all subsequent years, and the risk management index is only available for the year 2006, so I use the value for all firm years in the sample. I include each one of these four variables individually as well as each possible combination of the variables. The results are qualitatively unchanged; however, due to decreased sample size statistical significance is reduced in some of the specifications. 


\section{Chapter 6: Conclusion}

This paper investigates the effects on Tier 1 capital ratios of the requirement under the Dodd-Frank Act that large bank holding companies maintain a stand-alone risk committee on their board of directors. I find that while requiring a risk committee increases capital ratios during volatile economic conditions, it also decreases capital ratios in more stable environments. The results during the crisis are likely a desirable result of the legislation from a regulators perspective. However, the desirability of the evidence prior to the crisis, that the presence of a risk committee reduces capital ratios, is more uncertain. Even though the risk committee may always be acting in the best interest of the firm, the differing effects on the outcome measure that I document when comparing the pre-crisis period to the crisis period highlight the importance of considering time varying effects when examining the potential consequences of new regulation.

In further investigating the mechanisms through which these effects transpire, I

find that the results are driven by changes to the denominator of the Tier 1 capital ratio, risk weighted assets. This finding implies that board level risk committees are more involved with setting and approving credit policies and investment strategies than just recommending that new equity be issued or dividend policy be adjusted. While making significant changes to the asset holdings of an industrial firm can be difficult and time 
consuming, the liquid nature of most of the assets on a bank's balance sheet allows the risk committee to make the changes in a relatively short period of time.

I also contribute to the literature by showing that when there are voluntary adopters of a behavior that is being considered by regulators or standard setters it can be possible for archival research to provide ex ante evidence on the potential impact of that rule. The methods this paper highlights might also be useful in settings that are not yet on the radar of policy makers, but academics or other interested parties think should be considered for mandatory implementation. A caveat is that the mere presence of voluntary adopters does not ensure validity of the identification strategy, in addition there must exist a set of observable covariates strong enough to argue that conditional mean independence is satisfied and there must also be a region of overlap among those covariates between the voluntary adopters and the non-adopters.

To this point, the literature has relied upon theoretical models, lab experiments, or simulation studies in attempting to provide ex ante policy relevant research. While all of those methods remain useful and valid, the methods that I demonstrate in this paper provide one avenue through which archival research can also attempt to provide ex ante evidence that standard setters and policy makers will value. 


\section{References}

Acharya, V., and M. Richardson. 2009. Causes of the Financial Crisis. Critical Review: A Journal of Politics and Society, 21: 195 - 210.

Adams, R. 2009. Asking Directors about their Dual Roles. Working Paper, University of Queensland.

Adams, R., B. Hermalin and M. Weisbach. 2010. The Role of Boards of Directors in Corporate Governance: A Conceptual Framework and Survey. Journal of Economic Literature, 48(1): 58 - 107.

Aebi V., G. Sabato, and M. Schmid. 2012. Risk Management, Corporate Governance, and Bank Performance in the Financial Crisis. Journal of Banking and Finance, 36: 3213 -3226 .

Agrawal, A. and C. Knoeber. 2001. Do Some Outside Directors Play a Political Role? Journal of Law and Economics, 44(1): 179 - 198.

Ahmed, A., and S. Duellman. 2007. Accounting Conservatism and Board of Director Characteristics: An Empirical Analysis. Journal of Accounting and Economics, 43(2-3): $411-437$.

Anderson, R., S. Mansi, and D. Reeb. 2004. Board Characteristics, Accounting Report Integrity, and the Cost of Debt. Journal of Accounting and Economics, 37(3): 315 - 342.

Armstrong, C., A. Jagolinzer, and D. Larcker. 2010. Chief Executive Officer Equity Incentives and Accounting Irregularities. Journal of Accounting Research, 48(2): $225-$ 271.

Barth, M., W. Beaver, and W. Landsman. 2001. The Relevance of the Value Relevance Literature for Financial Accounting Standard Setting: Another View. Journal of Accounting and Economics, 31(1-3): 77 - 104.

Beasley, M. 1996. An Empirical Analysis of the Relation Between the Board of Director Composition and Financial Statement Fraud. The Accounting Review, 71: 443 - 465.

Bushman, R. and C. Williams. 2014. Delayed Expected Loss Recognition and the Risk Profile of Banks. Working Paper, Kenan-Flagler Business School University of North Carolina. 
Calem, P. and R. Rob. 1999. The Impact of Capital-Based Regulation on Bank RiskTaking. Journal of Financial Intermediation, 8: 317 - 352.

Caliendo M., and S. Kopeinig. 2008. Some Practical Guidance for the Implementation of Propensity Score Matching. Journal of Economic Surveys, 22: 31-72.

DeHaan, E., F. Hodge, and T. Shevlin. 2013. Does Voluntary Adoption of a Clawback Provision Improve Financial Reporting Quality? Contemporary Accounting Research, Forthcoming.

Demb, A. and F. Neubauer. 1992. The Corporate Board. Oxford. Oxford University Press.

Dewatripont, M., J. Rochet, and J Tirole. 2010. Balancing the Banks: Global Lessons from the Financial Crisis. New Jersey. Princeton University Press.

Diamond, D., and P. Dybvig. 1983. Bank Runs, Deposit Insurance, and Liquidity. Journal of Political Economy, 91: $401-419$.

Diamond, D. and R. Rajan. 2000. A Theory of Bank Capital. Journal of Finance, 55 (6): $2431-2465$

Diamond D., and R. Rajan. 2001. Liquidity Risk, Liquidity Creation and Financial Fragility: A Theory of Banking. Journal of Political Economy, 109: 287 - 327.

Dodd-Frank Wall Street Reform and Consumer Protection Act, Pub. L. No. 111-203 $\S 165(\mathrm{~h})(2010)$.

Ellul, A., and V. Yerramilli. 2013. Stronger Risk Controls, Lower Risk: Evidence from U.S. Bank Holding Companies. Journal of Finance, Forthcoming.

Estrella, A. 2004. The Cyclical Behavior of Optimal Bank Capital. Journal of Banking and Finance, 28: 1469 - 1498.

Fulbier, R., J. Hitz, and T. Sellhorn. 2009. Relevance of Academic Research and Researchers' Role in the IASB's Financial Reporting Standard Setting. ABACUS, 45(4): $455-492$.

Furfine, C. 2001. Bank Portfolio Allocation: The Impact of Capital Requirements, Regulatory Monitoring and Economic Conditions. Journal of Financial Services Research, 20: 33 - 56.

Gao, Y., S. Liao, and X Wang. 2013. The Economic Impact of the Dodd-Frank Act on Systemically Important Firms: Evidence from Market Reactions. Working Paper, Carlson School of Management, University of Minnesota. 
Gompers, P., J. Ishii and A. Metrick. 2003. Corporate Governance and Equity Prices. Quarterly Journal of Economics, 118(1): 107 - 156.

Gordy, M. and B. Howells. 2006. Procyclicality in Basel II: Can We Treat the Disease Without Killing the Patient? Journal of Financial Intermediation, 15: 395 - 417.

Greene, W. 2008. Econometric Analysis, $6^{\text {th }}$ Ed. New Jersey. Pearson Education, Inc.

Hahn, J. 1998. On the Role of the Propensity Score in Efficient Semiparametric Estimation of Average Treatment Effects. Econometrica, 66(2): 315 - 331.

Heckman, J. 1997. Instrumental Variables: A Study of Implicit Behavioral Assumptions Used in Making Program Evaluations. The Journal of Human Resources, 32: 441 - 462.

Heckman, J., H. Ichimura, and P. Todd. 1998. Matching as an Econometric Evaluation Estimator. The Review of Economic Studies, 65: 261 - 294.

Helland, E. and M. Sykuta. 2004. Regulation and the Evolution of Corporate Boards: Monitoring, Advising or Window Dressing? Journal of Law and Economics, 47(1): $167-193$.

Hermalin, B., and M. Weisbach. 1998. Endogenously Chosen Boards of Directors and Their Monitoring of the CEO. American Economic Review, 88: 96 - 118.

Holthausen, R., and R. Watts. 2001. The Relevance of the Value Relevance Literature for Financial Accounting Standard Setting. Journal of Accounting and Economics, 31(1-3): $3-75$.

Imbens, G., and J. Angrist. 1994. Identifcation and Estimation of Local Average Treatment Effects. Econometrica, 62(2): 467 - 475.

Imbens, G., and D. Rubin. 2012. Causal Inference in Statistics. Cambridge. Cambridge University Press.

Kachelmeier, S., and R. King. Using Laboratory Experiments to Evaluate Accounting Policy Issues. Accounting Horizons, 16(3): 219 - 232.

Karamanou, I., and N. Vafeas. 2005. The Association between Corporate Boards, Audit Committees, and Management Earnings Forecasts: An Empirical Analysis. Journal of Accounting Research, 43: 453 - 486.

Kashyap, A., R. Rajan, and J. Stein. 2008. Rethinking Capital Regulation. Maintaining Stability in a Changing Financial System, 431-71. Federal Reserve Bank of Kansas City. 
Kim, D., and A. M. Santomero. 1988. Risk in Banking and Capital Regulation. Journal of Finance, 43: 1219-1233.

Klein, A. 1998. Firm Performance and Board Committee Structure. Journal of Law and Economics, 41(1): 275 - 304.

Minton, B., J. Taillard, and R Williamson. 2014. Financial Expertise of the Board, Risk Taking, and Performance: Evidence from Bank Holding Companies. Journal of Financial and Quantitative Analysis. Forthcoming.

NYSE Listed Company Manual § 303A.07(b)(iii)(D)

Petersen, M. 2009. Estimating Standard Errors in Panel Data Sets. Review of Financial Studies, 22: 435 - 480.

Romano, R. 2005. Quack Corporate Governance. Regulation, 28(4): 36 - 44.

Rosenbaum, P., and D. Rubin. 1983. The Central Role of the Propensity Score in Observational Studies for Causal Effects. Biometrika, 70: 41 - 55.

Schipper, K. 1994. Academic Accounting Research and the Standard Setting Process. Accounting Horizons, 8(4): 61 - 73.

Schroeder, D. 2010 Accounting and Causal Effects: Econometric Challenges. New York. Springer Science + Business Media, LLC.

Skeel, D. 2011. The New Financial Deal. Wiley \& Sons, Inc. Hoboken, NJ.

Smith, J., and P. Todd. 2005. Does Matching Overcome LaLonde's Critique of Nonexperimental Estimators? Journal of Econometrics, 125(1-2): 305 - 353.

Tucker, J. 2010. Selection Bias and Econometric Remedies in Accounting and Finance Research. Journal of Accounting Literature, 29: 31 - 57.

Watts, R., and J. Zimmerman. 1979. The Demand for and Supply of Accounting Theories: The Market for Excuses. The Accounting Review, 54(2): 273 - 305.

Waymire, G., and Basu, S., 2007. Accounting Is an Evolved Economic Institution. Foundations and Trends in Accounting, 2: 1-174.

Wooldridge, J. 2011. Econometric Analysis of Cross Section and Panel Data $2^{\text {nd }}$ Edition. Cambridge. The MIT Press. 


\section{Appendix A: Variable Definitions}

\begin{tabular}{|c|c|c|}
\hline Variable & Definition & Data Source \\
\hline BDINDEP & $\begin{array}{l}\text { Percentage of the directors sitting on the board in a given year who are } \\
\text { classified as independent under the rules of Sarbanes-Oxley }\end{array}$ & $\begin{array}{l}\text { Collected from Proxy } \\
\text { Statements and } 10-\mathrm{Ks}\end{array}$ \\
\hline BDMEET & Number of full board meetings held during the year & $\begin{array}{l}\text { Collected from Proxy } \\
\text { Statements and 10-Ks }\end{array}$ \\
\hline BDSIZE & $\begin{array}{l}\text { Total number of directors serving on the board of directors in a given } \\
\text { year }\end{array}$ & $\begin{array}{l}\text { Collected from Proxy } \\
\text { Statements and } 10-\mathrm{Ks} \\
\end{array}$ \\
\hline BETA & $\begin{array}{l}\text { Coefficient estimate on the market index from regressing daily returns } \\
\text { (RET) on the value weighted market index (VWRETD) minus using } \\
\text { all trading days during the fiscal year }\end{array}$ & CRSP \\
\hline BTM & $\begin{array}{l}\text { Book value of total assets (ATQ) divided by market value of assets } \\
\text { calculated as book value of total assets (ATQ) + market value of } \\
\text { equity (PRCCQ * CSHOQ) - book value of equity (CEQQ) }\end{array}$ & Bank CompuStat \\
\hline CASH & $\begin{array}{l}\text { Total cash holdings (BHCK0081 + BHCK0395 + BHCK0397) as a } \\
\text { percentage of total assets (BHCK2170) }\end{array}$ & Form Y9-C \\
\hline CEOCHAIR & $\begin{array}{l}\text { Dummy variable equal to } 1 \text { if the CEO also serves as the chairman of } \\
\text { the board in the year of the observation and } 0 \text { otherwise }\end{array}$ & $\begin{array}{l}\text { Collected from Proxy } \\
\text { Statements and 10-Ks } \\
\end{array}$ \\
\hline CRISIS & $\begin{array}{l}\text { Dummy variable equal to } 1 \text { for all firm quarter observations after July } \\
2007 \text { and } 0 \text { for all firm quarter observations before July } 2007\end{array}$ & \\
\hline IDIOVOL & $\begin{array}{l}\text { Idiosyncratic return volatility measured as the standard deviation of } \\
\text { the residuals from a regression of daily stock returns (RET) on the } \\
\text { value weighted market index (VWRETD) using all trading days during } \\
\text { the prior quarter }\end{array}$ & CRSP \\
\hline INSTOWN & Percentage of shares held by institutions & Thompson Reuters \\
\hline LLR & $\begin{array}{l}\text { Total loan loss reserve (BHCK3123) as a percentage of total assets } \\
\text { (BHCK2170) }\end{array}$ & Form Y9-C \\
\hline NPL & $\begin{array}{l}\text { Total non performing loans (NPAT) as a percentage of total assets } \\
\text { (AT) }\end{array}$ & Bank CompuStat \\
\hline $\mathrm{RC}$ & $\begin{array}{l}\text { Dummy variable equal to } 1 \text { for all firm quarters if a risk committee } \\
\text { distinct from the audit committee is present on the board of directors } \\
\text { and } 0 \text { for all firm quarters without a stand-alone risk committee. }\end{array}$ & $\begin{array}{l}\text { Collected from Proxy } \\
\text { Statements and } 10-\mathrm{Ks}\end{array}$ \\
\hline ROA & $\begin{array}{l}\text { Return on assets defined as net income before extraordinary items } \\
(\mathrm{BHCK} 4300) \text { as a percentage of average total assets }\left(\left(\mathrm{BHCK} 2170_{\mathrm{t}}+\right.\right. \\
\left.\left.\text { BHCK } 2170_{\mathrm{t}-1}\right) / 2\right)\end{array}$ & Form Y9-C \\
\hline SECURITIZED & $\begin{array}{l}\text { Total securitized assets (BHCKB705 thru BHCKB711) as a } \\
\text { percentage of total assets (BHCK2170) }\end{array}$ & Form Y9-C \\
\hline SIZE & Natural logarithm of total assets (BHCK2170) & Form Y9-C \\
\hline TIER1 & $\begin{array}{l}\text { Tier } 1 \text { risk weighted capital ratio calculated as Total Tier } 1 \text { Assets } \\
\text { (BHCK8274) as a percentage of Total Risk Weighted Assets } \\
\text { (BHCKA223) }\end{array}$ & $\begin{array}{l}\text { Form Y9-C / Bank } \\
\text { CompuStat }\end{array}$ \\
\hline TRADING & $\begin{array}{l}\text { Total trading assets (BHCK3545) as a percentage of total assets } \\
\text { (BHCK2170) }\end{array}$ & Form Y9-C \\
\hline
\end{tabular}




\section{Appendix B: Numerical Example of Differences between Average Treatment on Treated (ATT) and Average Treatment on Untreated (ATUT)}

\begin{tabular}{|c|ccc|ccc|}
\cline { 2 - 7 } \multicolumn{1}{c|}{} & \multicolumn{3}{c|}{ Observables } & \multicolumn{3}{c|}{ Unobservables } \\
\hline$(1)$ & $(2)$ & $(3)$ & $(4)$ & $(5)$ & $(6)$ & $(7)$ \\
ID & RC & $\mathrm{Y}$ & $\mathrm{X}$ & $\mathrm{Y}_{1}$ & $\mathrm{Y}_{0}$ & $\mathrm{TE}$ \\
\hline 1 & 0 & 9 & 1 & 6 & 9 & -3 \\
2 & 0 & 10 & 1 & 8 & 10 & -2 \\
3 & 0 & 11 & 1 & 10 & 11 & -1 \\
4 & 1 & 8 & 1 & 8 & 10 & -2 \\
5 & 0 & 7 & 0 & 9 & 7 & 2 \\
6 & 1 & 9 & 0 & 9 & 6 & 3 \\
7 & 1 & 8 & 0 & 8 & 7 & 1 \\
8 & 1 & 10 & 0 & 10 & 8 & 2 \\
\hline
\end{tabular}

The above chart describes a sample data generating process for eight observations in which the ATT is not equal to the ATUT, and in fact the two are of opposite sign. Column (1) is just an identifier for each observation. Column (2) is a dummy variable $\mathrm{RC}$ identifying whether or not the observation is treated. Column (3) represents the observed outcome measure Y. Column (4) represents an observed covariate X. In this setting $X$ is a single covariate that takes the value of either 0 or 1 but it can be easily extended to a multidimensional vector of covariates. The researcher only observes Columns (2), (3), and (4).

Columns (5) thru (7) represent unobservable quantities that underly the observable outcome Y. Column (5) represents outcome if the observation is treated, $Y_{1}$. Column (6) represents outcome if the observation is not treated, $\mathrm{Y}_{0}$. Column (7) represents the individual level treatment effect, TE, which is simply $\mathrm{Y}_{1}-\mathrm{Y}_{0}$. To understand how the unobservables drive the observable outcome, compare $Y$ to both $Y_{1}$ and $Y_{0}$ conditional on RC. Notice that whenever $\mathrm{RC}=1, \mathrm{Y}=\mathrm{Y}_{1}$, and whenever $\mathrm{RC}=0, \mathrm{Y}=\mathrm{Y}_{0}$.

With this setup three different treatment effects can be measured. The average treatment effect (ATE), the ATT, and the ATUT. The true values of these effects (not observable by the researcher) are presented below.

$\mathrm{ATE}=\mathrm{E}\left[\mathrm{Y}_{1}-\mathrm{Y}_{0}\right]=0$

(the average TE for all 8 observations)

$\mathrm{ATT}=\mathrm{E}\left[\mathrm{Y}_{1}-\mathrm{Y}_{0} \mid \mathrm{RC}=1\right]=1 \quad$ (the average TE for the 4 observations where $\left.\mathrm{RC}=1\right)$ $\mathrm{ATUT}=\mathrm{E}\left[\mathrm{Y}_{1}-\mathrm{Y}_{0} \mid \mathrm{RC}=0\right]=-1 \quad($ the average $\mathrm{TE}$ for the 4 observations where $\mathrm{RC}=0)$ 
This is clearly a setting where identifying the appropriate treatment effect is important. Not only are the effects on the treated and untreated populations different, but they are of opposite signs. Thus drawing conclusions about the effect on the untreated population from identification of the ATT would lead to incorrect inferences.

Below are the steps that are used to execute the identification strategy employed by this paper to estimate the ATUT in this numerical example.

The first involves estimating the propensity score, in this case there is only one covariate, $\mathrm{X}$, so the propensity score reduces to $\mathrm{X}$. The next step is to find a match for every observation where $\mathrm{RC}=0$ from the pool of observations where $\mathrm{RC}=1$. The resulting matched sample is presented below. Each untreated observation is followed on the next row by its matched treated observation. The observable values are reproduced in the table. ${ }^{16}$

\begin{tabular}{|cccc|}
\hline$(1)$ & $(2)$ & $(3)$ & $(4)$ \\
ID & $\mathrm{RC}$ & $\mathrm{X}$ & $\mathrm{Y}$ \\
\hline 1 & 0 & 1 & 9 \\
4 & 1 & 1 & 8 \\
\hline 2 & 0 & 1 & 10 \\
4 & 1 & 1 & 8 \\
\hline 3 & 0 & 1 & 11 \\
4 & 1 & 1 & 8 \\
\hline 5 & 0 & 0 & 7 \\
6 & 1 & 0 & 9 \\
\hline
\end{tabular}

Now that the matched sample has been derived the final step is to rely on conditional mean independence and regress $\mathrm{Y}$ on RC to get an estimate of ATUT. Running this regression produces the following coefficient estimates.

$\mathrm{Y}=9.25-1 * \mathrm{RC}$

The coefficient estimate on RC (-1) is the estimate of ATUT and because conditional mean independence holds in the data generating process the estimate of ATUT is unbiased.

\footnotetext{
${ }^{16}$ Observations 6, 7 and 8 are all equally good matches for observation 5. I use the average outcome of these three observations which equals outcome for observation 6 . Alternatively, all three observations could have been included as matches and weighted equally in a weighted least squares regression and the results would remain unchanged.
} 
As a final point, to see that conditional mean independence for outcome with treatment holds in this example evaluate the following (using data that is unobservable to the researcher):

$\mathrm{E}\left[\mathrm{Y}_{1} \mid \mathrm{RC}=1, \mathrm{X}=1\right]=8 \quad$ (expectation of observation 4$)$

$\mathrm{E}\left[\mathrm{Y}_{1} \mid \mathrm{RC}=0, \mathrm{X}=1\right]=8 \quad$ (expectation of observations 1, 2 and 3 )

$\mathrm{E}\left[\mathrm{Y}_{1} \mid \mathrm{RC}=1, \mathrm{X}=0\right]=9 \quad$ (expectation of observations 6,7 and 8 )

$\mathrm{E}\left[\mathrm{Y}_{1} \mid \mathrm{RC}=0, \mathrm{X}=0\right]=9 \quad$ (expectation of observation 5)

Note that this test of CMI relies on outcomes that are never observed by the researcher $\left(\mathrm{E}\left[\mathrm{Y}_{1} \mid \mathrm{RC}=0\right]\right)$. Therefore the assumption cannot be tested in practice with observable data. 


\section{Panel A: Before Matching}

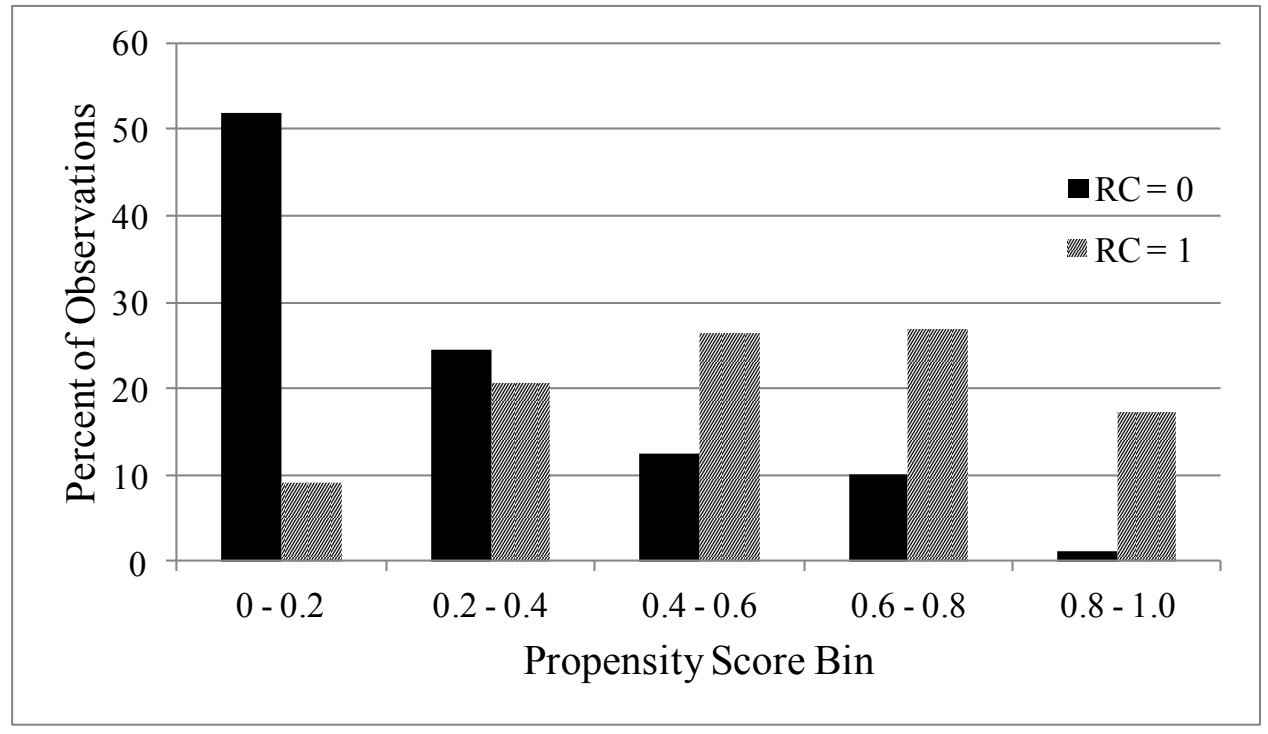

\section{Panel B: After Matching}

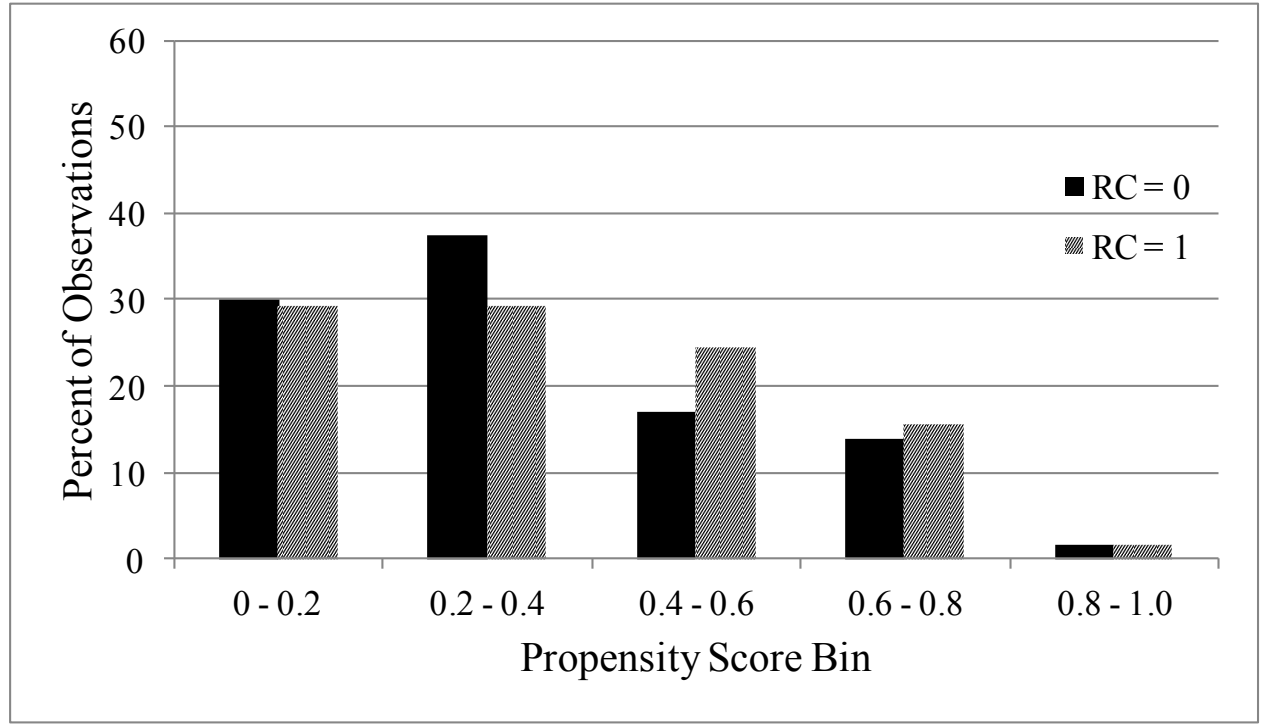

Figure 1: Distribution of Propensity Scores for ATUT Sample

This figure presents the distribution of propensity scores separately for firms with and without a risk committee. Panel A presents the distributions of the sample before the propensity score matching is done. Panel B presents the distributions of the sample after the propensity score matching procedures are implemented. 
$\operatorname{TIER}_{i, t}=\alpha+\beta_{1} R C_{i, t}+\beta_{2}$ CRISIS $_{t}+\beta_{3}$ CRISIS $_{t} \times R C_{i, t}+\sum \gamma_{k} \operatorname{CONTROLS}+\varepsilon_{i, t}$

\begin{tabular}{|c|c|c|c|}
\cline { 2 - 4 } \multicolumn{1}{c|}{} & $\begin{array}{c}\text { CRISIS }=\mathbf{0} \\
\text { (1) }\end{array}$ & $\begin{array}{c}\text { CRISIS }=\mathbf{1} \\
\text { (2) }\end{array}$ & $\begin{array}{c}\text { Change Pre to Post } \\
\text { (3) }\end{array}$ \\
\hline $\mathbf{R C}=\mathbf{0}$ & $\alpha$ & $\alpha+\beta_{2}$ & $\beta_{2}$ \\
\hline $\mathbf{R C}=\mathbf{1}$ & $\alpha+\beta_{1}$ & $\alpha+\beta_{1}+\beta_{2}+\beta_{3}$ & $\beta_{2}+\beta_{3}$ \\
\hline ATUT & $\beta_{1}$ & $\beta_{1}+\beta_{3}$ & $\beta_{3}$ \\
\hline
\end{tabular}

Figure 2: Interpretation of Regression Coefficients in Interaction Regression

This figure depicts the interpretation of the coefficients in the main regression. Column (1) presents the coefficients for the pre-crisis period when CRISIS takes a value of 0 . The bottom row shows that the average treatment effect on the untreated in the pre-crisis period is identified by the coefficient estimate $\beta_{1}$. Column (2) presents the coefficients for the crisis period when CRISIS takes a value of 1 . The bottom row shows that the ATUT in the crisis period is identified by the sum of the coefficient estimates $\beta_{1}+\beta_{3}$. Column (3) presents the coefficients for the change from the pre-crisis period to the crisis period. The bottom row shows that the change int the ATUT from the pre-crisis period to the crisis period is identified by the coefficient estimate $\beta_{3}$. 


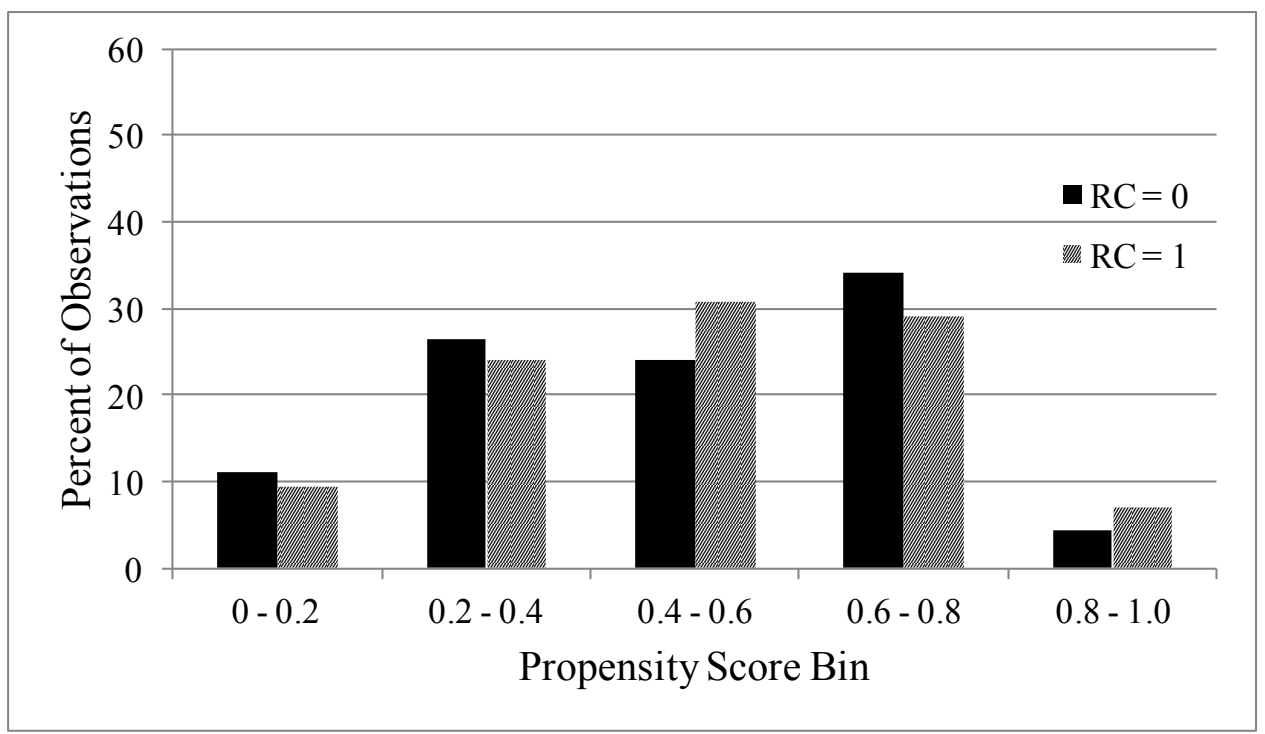

Figure 3: Distribution of Propensity Scores for ATT Sample After Matching

This figure presents the distribution of propensity scores separately for firms with and without a risk committee after the propensity score matching procedures are implemented for the sample used to estimate the Average Treatment Effect on the Treated. 


\begin{tabular}{|c|c|c|c|c|c|}
\hline \multicolumn{6}{|c|}{ Table 1} \\
\hline & $\begin{array}{c}\text { RCFIRST }=1 \\
\text { (1) }\end{array}$ & $\begin{array}{c}\mathrm{RC}=1 \\
(2)\end{array}$ & $\begin{array}{c}\mathrm{RC}=0 \\
(3)\end{array}$ & $\begin{array}{c}\text { Total Banks } \\
\text { (4) }\end{array}$ & $\begin{array}{c}\text { \% Banks } \\
\text { with RC } \\
\text { (5) }\end{array}$ \\
\hline Pre-2004 & 9 & & & & \\
\hline 2004 & 7 & 16 & 53 & 69 & $23.2 \%$ \\
\hline 2005 & 2 & 18 & 48 & 66 & $27.3 \%$ \\
\hline 2006 & 4 & 21 & 45 & 66 & $31.8 \%$ \\
\hline 2007 & 1 & 20 & 40 & 60 & $33.3 \%$ \\
\hline 2008 & 3 & 22 & 36 & 58 & $37.9 \%$ \\
\hline 2009 & 7 & 27 & 26 & 53 & $50.9 \%$ \\
\hline 2010 & 5 & 32 & 22 & 54 & $59.3 \%$ \\
\hline \multicolumn{6}{|c|}{$\begin{array}{l}\text { This table presents a yearly breakdown of risk committee creation and existence for banks } \\
\text { included in the sample. Column (1) shows the number of banks that created a risk committee } \\
\text { in a given year. Column (2) shows the number of banks in the sample that had a risk } \\
\text { committee in place by the end of a given year. In some instances the sum of the number of } \\
\text { banks that had a risk committe in place at the end of the prior year and the number of banks } \\
\text { that created a committee in a given year do not add up to the total number of banks with a risk } \\
\text { committee at the end of the year because banks either merge or drop out of the sample. There } \\
\text { are no instances of a bank that has a risk committee in place removing that committee at a } \\
\text { later date. Column (3) shows the number of banks in the sample that did not have a risk } \\
\text { committee in place by the end of a given year. Column (4) shows the total number of banks in } \\
\text { the sample at the end of a given year. Column (5) shows the percentage of banks in the } \\
\text { sample that have a risk committee in place by the end of a given year. }\end{array}$} \\
\hline
\end{tabular}


Table 2

Descriptive Statistics

\section{Panel A: Distributional Statistics}

\begin{tabular}{lrrrrr} 
& Mean & Std & P10 & Median & P90 \\
\cline { 2 - 5 } RC & 0.364 & 0.481 & 0.000 & 0.000 & 1.000 \\
TIER1 & 11.002 & 2.921 & 8.210 & 10.540 & 13.930 \\
SIZE & 17.190 & 1.431 & 15.851 & 16.679 & 18.981 \\
IDIOVOL & 1.899 & 1.689 & 0.671 & 1.263 & 4.014 \\
BETA & 1.246 & 0.558 & 0.673 & 1.137 & 1.935 \\
CASH & 4.235 & 5.114 & 1.437 & 2.792 & 7.659 \\
TRADING & 0.016 & 0.044 & 0.000 & 0.001 & 0.033 \\
SECURITIZED & 0.065 & 0.191 & 0.000 & 0.000 & 0.186 \\
BTM & 0.941 & 0.063 & 0.862 & 0.937 & 1.030 \\
INSTOWN & 0.564 & 0.197 & 0.293 & 0.576 & 0.821 \\
LLR & 1.028 & 0.623 & 0.467 & 0.869 & 1.849 \\
NPL & 1.183 & 1.625 & 0.136 & 0.533 & 3.108 \\
ROA & 0.507 & 0.763 & -0.054 & 0.544 & 1.251 \\
BDSIZE & 13.350 & 3.249 & 9.000 & 13.000 & 17.000 \\
BDINDEP & 0.795 & 0.096 & 0.667 & 0.800 & 0.917 \\
BDMEET & 9.929 & 4.698 & 5.000 & 9.000 & 15.000 \\
CEOCHAIR & 0.734 & 0.442 & 0.000 & 1.000 & 1.000 \\
& & & & & \\
\hline This & & &
\end{tabular}

This table presents mean, standard deviation, 10th percentile, median and 90th percentile for each variable used in this study. Distributional statistics are reported for the full time series of data which includes 1,743 bank-quarter observations. All variables are defined in Appendix A.

Continued 
Table 2: Continued

Panel B: Pearson (Spearman) Correlations Above (Below) the Diagonal

\begin{tabular}{|c|c|c|c|c|c|c|c|c|c|c|c|c|c|c|c|c|c|}
\hline & (1) & (2) & (3) & (4) & (5) & (6) & (7) & (8) & (9) & (10) & (11) & (12) & (13) & $(1$ & (15) & f) & (17) \\
\hline $\mathrm{RC}$ & & -0.081 & 0.259 & 0.196 & 0.152 & 0.099 & 0.099 & -0.045 & 0.342 & 0.080 & 0.196 & 0.278 & -0.198 & -0.091 & 0.260 & 0.167 & 0.016 \\
\hline (2) TIER1 & -0.079 & & -0.261 & 0.047 & 0.049 & 0.161 & -0.140 & 0.048 & .004 & 0.070 & 0.016 & 0.090 & -0.059 & -0.203 & -0.119 & 0.176 & -0.136 \\
\hline (3) SIZE & 0.307 & -0.307 & & 0.010 & 0.060 & 0.117 & 0.685 & 0.368 & 0.173 & 0.177 & 0.100 & 0.082 & 0.041 & 0.229 & 0.269 & 0.105 & 0.151 \\
\hline (4) IDIOVOL & 0.153 & 0.251 & -0.071 & & 0.617 & 0.074 & -0.023 & 0.012 & 0.622 & 0.119 & 0.485 & 0.589 & -0.592 & -0.171 & -0.014 & 0.320 & -0.120 \\
\hline (5) BETA & 0.131 & 0.135 & -0.022 & 0.595 & & -0.002 & 0.047 & 0.030 & 0.485 & 0.247 & 0.269 & 0.352 & -0.301 & -0.145 & 0.024 & 0.265 & -0.081 \\
\hline (6) $\mathrm{CASH}$ & -0.010 & 0.155 & 0.169 & 0.003 & 0.051 & & 0.079 & -0.049 & 0.023 & 0.201 & 0.073 & 0.021 & -0.071 & 0.033 & 0.244 & -0.010 & -0.025 \\
\hline (7) TRADING & 0.222 & -0.202 & 0.675 & -0.091 & 0.000 & 0.346 & & 0.308 & 0.083 & 0.203 & -0.027 & 0.085 & 0.009 & 0.101 & 0.134 & 0.168 & -0.030 \\
\hline (8) SECURITIZ & 0.113 & -0.238 & 0.573 & -0.036 & 0.000 & 0.041 & 0.416 & & 0.136 & 0.111 & 0.087 & 0.209 & 0.009 & 0.004 & 0.116 & 0.157 & -0.029 \\
\hline (9) $\mathrm{B}$ & 0.355 & 0.102 & 0.194 & 0.605 & 0.512 & -0.040 & 0.123 & -0.003 & & 0.087 & 0.510 & 0.570 & -0.564 & -0.086 & 0.069 & 0.244 & -0.071 \\
\hline 0) 1 & 0.104 & 0.099 & 0.184 & 0.234 & 0.227 & 0.223 & 0.100 & 0.196 & 0.118 & & 0.061 & 0.072 & -0.030 & -0.150 & 0.259 & 0.100 & -0.032 \\
\hline 1) LLR & 0.159 & 0.043 & 0.101 & 0.380 & 0.339 & -0.069 & -0.049 & 0.086 & 0.457 & 0.022 & & 0.725 & -0.521 & -0.148 & 0.103 & 0.230 & -0.111 \\
\hline PL & 0.318 & 0.031 & 0.236 & 0.530 & 0.352 & 0.045 & -0.018 & 0.088 & 0.689 & 0.108 & 0.688 & & -0.550 & -0.230 & 0.050 & 0.323 & -0.151 \\
\hline 13) $\mathrm{ROA}$ & -0.220 & -0.153 & 0.026 & -0.486 & -0.353 & -0.080 & -0.008 & 0.082 & -0.587 & -0.064 & -0.367 & -0.451 & & 0.089 & -0.024 & -0.239 & 0.107 \\
\hline (14) BDSIZE & -0.071 & -0.196 & 0.246 & -0.185 & -0.137 & 0.131 & 0.228 & 0.050 & -0.082 & -0.122 & -0.142 & -0.135 & 0.096 & & 0.092 & -0.206 & 0.126 \\
\hline 15) BDINDEP & 0.288 & -0.103 & 0.229 & -0.025 & 0.049 & 0.311 & 0.349 & 0.092 & 0.078 & 0.281 & 0.040 & 0.125 & -0.014 & 0.103 & & -0.062 & -0.056 \\
\hline 6) 1 & 0.136 & 0.207 & 0.017 & 0.315 & 0.254 & -0.052 & 0.000 & 0.117 & 0.233 & 0.157 & 0.172 & 0.217 & -0.229 & -0.207 & -0.053 & & -0.129 \\
\hline 7) CEOCHAIR & 0.016 & -0.170 & 0.230 & -0.143 & -0.089 & -0.108 & 0.063 & 0.112 & -0.079 & -0.033 & -0.065 & -0.141 & 0.099 & 0.120 & -0.04 & -0.086 & \\
\hline
\end{tabular}

This table presents Pearson correlations above the diagonal and Spearman correlations below the diagonal. All varables are defined in Appendix A. Correlations in bold are significantly different from zero at the $5 \%$ level. 
Table 3

Propensity Score Model

\begin{tabular}{|c|c|c|}
\hline & Dep & \\
\hline & $\begin{array}{r}\text { Coeff } \\
\text { (1) }\end{array}$ & $\begin{array}{l}\text { SE } \\
(2)\end{array}$ \\
\hline TIER $1_{t-1}$ & -0.080 & $(0.086)$ \\
\hline $\mathrm{SIZE}_{\mathrm{t}-1}$ & 0.676 & $(0.287) * *$ \\
\hline IDIOVOL $_{t-1}$ & -0.208 & $(0.117) *$ \\
\hline BETA $_{t-1}$ & -0.066 & $(0.314)$ \\
\hline $\mathrm{CASH}_{\mathrm{t}-1}$ & 0.019 & $(0.053)$ \\
\hline TRADING $_{\mathrm{t}-1}$ & -11.912 & (8.164) \\
\hline SECURITIZED $_{\mathrm{t}-1}$ & -2.944 & $(2.188)$ \\
\hline $\mathrm{BTM}_{\mathrm{t}-1}$ & 17.436 & $(6.553) * *$ \\
\hline INSTOWN $_{\mathrm{t}-1}$ & -0.547 & $(1.246)$ \\
\hline $\operatorname{LLR}_{\mathrm{t}-1}$ & -0.706 & $(0.615)$ \\
\hline $\mathrm{NPL}_{\mathrm{t}-1}$ & 0.246 & $(0.225)$ \\
\hline $\mathrm{ROA}_{t-1}$ & -0.135 & $(0.356)$ \\
\hline BDSIZE $_{\mathrm{t}-1}$ & -0.128 & $(0.080)$ \\
\hline BDINDEP $_{t-1}$ & 6.573 & $(2.230) * * *$ \\
\hline $\mathrm{BDMEET}_{\mathrm{t}-1}$ & 0.055 & $(0.049)$ \\
\hline CEOCHAIR $_{\mathrm{t}-1}$ & 0.013 & $(0.533)$ \\
\hline TIME & -0.071 & $(0.124)$ \\
\hline INTERCEPT $_{\mathrm{t}-1}$ & -30.178 & $(8.038) * * *$ \\
\hline $\mathrm{N}$ & 42 & \\
\hline Psuedo $\mathrm{R}^{2}$ & 0.2 & \\
\hline SE Cluster & Fir & \\
\hline $\begin{array}{l}\text { This table presents th } \\
\text { committee at the begi } \\
\text { regression is run usin } \\
\text { reports. Column (1)p } \\
\text { standard errors that a } \\
\text { A. } * * *, * * \text { and } * \text { ind } \\
\text { respectively. }\end{array}$ & $\begin{array}{l}\text { tic regressi } \\
\text { ear on lagg } \\
\text { the } 4 \text { th qu } \\
\text { t estimates } \\
\text { m. All varial } \\
\text { nificance at }\end{array}$ & $\begin{array}{l}\text { resence of a risk } \\
\text { racteristics. The } \\
\text { Form Y9-C } \\
\text { (2) presents } \\
\text { fined in Appendix } \\
0 \text {, and } 10 \% \text { level, }\end{array}$ \\
\hline
\end{tabular}




\section{Table 4}

\section{Covariate Balance}

\begin{tabular}{|c|c|c|c|c|c|}
\hline \multicolumn{6}{|c|}{ Panel A: Include all risk committee firms as potential matches } \\
\hline & \multicolumn{2}{|c|}{$\mathrm{RC}=1$} & \multicolumn{2}{|c|}{$\mathrm{RC}=0$} & \multirow{2}{*}{$\begin{array}{r}\text { Normalized } \\
\text { Difference } \\
(5)\end{array}$} \\
\hline & $\begin{array}{r}\text { Mean } \\
\text { (1) }\end{array}$ & $\begin{array}{r}\text { Std } \\
\text { (2) }\end{array}$ & $\begin{array}{r}\text { Mean } \\
\text { (3) }\end{array}$ & $\begin{array}{l}\text { Std } \\
\text { (4) }\end{array}$ & \\
\hline P-SCORE & 0.368 & 0.188 & 0.351 & 0.190 & 0.064 \\
\hline TIER $1_{t-1}$ & 11.003 & 2.745 & 10.885 & 2.206 & 0.033 \\
\hline $\mathrm{SIZE}_{\mathrm{t}-1}$ & 17.260 & 1.197 & 17.010 & 1.095 & 0.154 \\
\hline IDIOVOL $_{t-1}$ & 2.151 & 1.887 & 1.761 & 1.321 & 0.169 \\
\hline BETA $_{t-1}$ & 1.342 & 0.646 & 1.215 & 0.543 & 0.151 \\
\hline $\mathrm{CASH}_{\mathrm{t}-1}$ & 4.239 & 4.905 & 3.947 & 4.211 & 0.045 \\
\hline TRADING $_{\mathrm{t}-1}$ & 0.020 & 0.057 & 0.005 & 0.010 & 0.248 \\
\hline SECURITIZED $_{\mathrm{t}-1}$ & 0.057 & 0.118 & 0.046 & 0.115 & 0.067 \\
\hline $\mathrm{BTM}_{\mathrm{t}-1}$ & 0.946 & 0.063 & 0.944 & 0.054 & 0.028 \\
\hline INSTOWN $_{t-1}$ & 0.589 & 0.196 & 0.541 & 0.212 & 0.166 \\
\hline $\mathrm{LLR}_{\mathrm{t}-1}$ & 1.053 & 0.620 & 1.015 & 0.569 & 0.044 \\
\hline $\mathrm{NPL}_{\mathrm{t}-1}$ & 1.395 & 1.686 & 1.066 & 1.342 & 0.152 \\
\hline $\mathrm{ROA}_{t-1}$ & 0.507 & 0.713 & 0.571 & 0.666 & -0.065 \\
\hline BDSIZE $_{t-1}$ & 13.155 & 3.662 & 13.460 & 3.167 & -0.063 \\
\hline BDINDEP $_{t-1}$ & 0.800 & 0.085 & 0.794 & 0.083 & 0.052 \\
\hline $\mathrm{BDMEET}_{\mathrm{t}-1}$ & 9.472 & 4.077 & 8.973 & 3.803 & 0.089 \\
\hline CEOCHAIR $_{\mathrm{t}-1}$ & 0.935 & 0.247 & 0.787 & 0.410 & 0.309 \\
\hline
\end{tabular}

This table presents comparisons of the means and standard deviations across the $\mathrm{RC}=0$ subsample and the matched $\mathrm{RC}=1$ subsample that result from the propensity score matching procedure. The matches in this table use all possible risk committee firms as the pool of potential matches. The row labeled P-SCORE represents the propensity score estimated from Table 3. Column (1) and (3) present means for the treated and untreated firm quarters respectively. Columns (2) and (4) present standard deviations for the treated and untreated firms respectively. Column (5) calculates the normalized difference following Wooldridge (2011) and Imbens and Rubin (2012) calculated as:

$(\operatorname{Mean}(\mathrm{X} \mid \mathrm{RC}=1)-\operatorname{Mean}(\mathrm{X} \mid \mathrm{RC}=0)) / \sqrt{ }\left(\operatorname{Std}(\mathrm{X} \mid \mathrm{RC}=1)^{2}+\operatorname{Std}(\mathrm{X} \mid \mathrm{RC}=0)^{2}\right)$.

The rule of thumb is that absolute normalized differences greater 0.25 are cause for concern.

Normalized differences that exceed the recommended threshold are highlighted in bold. 
Table 4: Continued

\begin{tabular}{|c|c|c|c|c|c|}
\hline \multicolumn{6}{|c|}{$\begin{array}{l}\text { Panel B: Include only risk committee firn } \\
\text { chair as potential matches }\end{array}$} \\
\hline 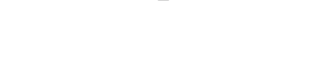 & \multicolumn{2}{|c|}{$\mathrm{RC}=1$} & \multicolumn{2}{|c|}{$\mathrm{RC}=0$} & \multirow{3}{*}{$\begin{array}{r}\text { Normalized } \\
\text { Difference } \\
(5)\end{array}$} \\
\hline & Mean & Std & Mean & Std & \\
\hline & $(1)$ & $(2)$ & (3) & (4) & \\
\hline P-SCORE & 0.389 & 0.159 & 0.366 & 0.186 & 0.094 \\
\hline TIER $1_{t-1}$ & 10.644 & 3.048 & 10.868 & 2.222 & -0.059 \\
\hline $\mathrm{SIZE}_{\mathrm{t}-1}$ & 17.420 & 1.139 & 17.055 & 1.116 & 0.229 \\
\hline IDIOVOL $_{t-1}$ & 2.188 & 2.062 & 1.740 & 1.334 & 0.182 \\
\hline BETA $_{t-1}$ & 1.344 & 0.729 & 1.203 & 0.545 & 0.154 \\
\hline $\mathrm{CASH}_{\mathrm{t}-1}$ & 2.904 & 1.452 & 4.011 & 4.337 & -0.242 \\
\hline TRADING $_{\mathrm{t}-1}$ & 0.011 & 0.018 & 0.006 & 0.010 & 0.266 \\
\hline SECURITIZED $_{\mathrm{t}-1}$ & 0.143 & 0.240 & 0.050 & 0.119 & 0.348 \\
\hline $\mathrm{BTM}_{\mathrm{t}-1}$ & 0.961 & 0.058 & 0.945 & 0.054 & 0.211 \\
\hline INSTOWN $_{\mathrm{t}-1}$ & 0.630 & 0.203 & 0.541 & 0.216 & 0.298 \\
\hline $\mathrm{LLR}_{\mathrm{t}-1}$ & 1.191 & 0.666 & 1.013 & 0.576 & 0.202 \\
\hline $\mathrm{NPL}_{\mathrm{t}-1}$ & 1.434 & 1.342 & 1.089 & 1.370 & 0.180 \\
\hline $\mathrm{ROA}_{\mathrm{t}-1}$ & 0.419 & 0.648 & 0.564 & 0.671 & -0.155 \\
\hline BDSIZE $_{\mathrm{t}-1}$ & 13.661 & 3.033 & 13.606 & 3.179 & 0.012 \\
\hline BDINDEP $_{t-1}$ & 0.817 & 0.074 & 0.801 & 0.080 & 0.143 \\
\hline $\mathrm{BDMEET}_{\mathrm{t}-1}$ & 9.026 & 2.836 & 8.998 & 3.804 & 0.006 \\
\hline CEOCHAIR $_{\mathrm{t}-1}$ & 0.948 & 0.223 & 0.807 & 0.395 & 0.310 \\
\hline
\end{tabular}

This table presents comparisons of the means and standard deviations across the $\mathrm{RC}=0$ subsample and the matched $\mathrm{RC}=1$ subsample that result from the propensity score matching procedure. The matches in this table use only risk committee firms that have both a risk expert on the committee and an outside director serving as the chair of the committee as the pool of potential matches. The row labeled P-SCORE represents the propensity score estimated from Table 3. Column (1) and (3) present means for the treated and untreated firm quarters respectively. Columns (2) and (4) present standard deviations for the treated and untreated firms respectively. Column (5) calculates the normalized difference following Wooldridge (2011) and Imbens and Rubin (2012) calculated as:

$(\operatorname{Mean}(\mathrm{X} \mid \mathrm{RC}=1)-\mathrm{Mean}(\mathrm{X} \mid \mathrm{RC}=0)) / \sqrt{ }\left(\operatorname{Std}(\mathrm{X} \mid \mathrm{RC}=1)^{2}+\operatorname{Std}(\mathrm{X} \mid \mathrm{RC}=0)^{2}\right)$.

The rule of thumb is that absolute normalized differences greater 0.25 are cause for concern. Normalized differences that exceed the recommended threshold are highlighted in bold. 
Table 5

The Effect of Risk Committee on Tier 1 Capital for Mandatory Adopters (ATUT)

\begin{tabular}{|c|c|c|c|c|}
\hline \multirow{4}{*}{$\begin{array}{l}\text { Panel A: Regression Results } \\
\text { Require Risk Expert and Outside Chair }\end{array}$} & \multicolumn{4}{|c|}{ Dep Var $=$ TIER1 } \\
\hline & \multicolumn{2}{|c|}{ No } & \multicolumn{2}{|c|}{ Yes } \\
\hline & Coeff & $\mathrm{SE}$ & Coeff & SE \\
\hline & (1) & (2) & (3) & (4) \\
\hline $\mathrm{RC}$ & -0.900 & $(0.477)^{*}$ & -1.264 & $(0.374) * * *$ \\
\hline CRISIS & -1.986 & $(0.696) * * *$ & -2.739 & $(0.627) * * *$ \\
\hline RC*CRISIS & 2.063 & $(0.954) * *$ & 3.784 & $(0.557) * * *$ \\
\hline $\mathrm{SIZE}_{\mathrm{t}-1}$ & -0.574 & $(0.228) * *$ & -0.427 & $(0.274)$ \\
\hline IDIOVOL $_{\mathrm{t}-1}$ & -0.258 & $(0.089) * * *$ & -0.067 & $(0.059)$ \\
\hline BETA $_{t-1}$ & 0.391 & $(0.335)$ & 0.353 & $(0.246)$ \\
\hline $\mathrm{CASH}_{\mathrm{t}-1}$ & 0.123 & $(0.048) * *$ & 0.169 & $(0.072) * *$ \\
\hline TRADING $_{\mathrm{t}-1}$ & 2.844 & $(3.610)$ & -33.752 & $(13.089) * *$ \\
\hline SECURITIZED $_{\mathrm{t}-1}$ & 0.420 & $(1.850)$ & 1.124 & $(1.231)$ \\
\hline $\mathrm{BTM}_{\mathrm{t}-1}$ & 5.594 & $(4.556)$ & 2.910 & $(5.818)$ \\
\hline INSTOWN $_{\mathrm{t}-1}$ & 0.055 & $(0.689)$ & -1.625 & $(0.816) *$ \\
\hline $\operatorname{LLR}_{\mathrm{t}-1}$ & -0.763 & $(0.787)$ & -0.183 & $(0.599)$ \\
\hline $\mathrm{NPL}_{\mathrm{t}-1}$ & 0.597 & $(0.403)$ & 0.459 & $(0.383)$ \\
\hline $\mathrm{ROA}_{\mathrm{t}-1}$ & 0.421 & $(0.191) * *$ & 0.363 & $(0.281)$ \\
\hline BDSIZE $_{t-1}$ & -0.054 & $(0.057)$ & -0.037 & $(0.070)$ \\
\hline BDINDEP $_{t-1}$ & -6.348 & $(2.030) * * *$ & -5.212 & $(2.213) * *$ \\
\hline BDMEET $_{t-1}$ & -0.002 & $(0.066)$ & 0.030 & $(0.059)$ \\
\hline CEOCHAIR $_{\mathrm{t}-1}$ & -0.084 & $(0.443)$ & -0.638 & $(0.460)$ \\
\hline TIME & 0.500 & $(0.137) * * *$ & 0.686 & $(0.153) * * *$ \\
\hline INTERCEPT & 19.567 & $(5.147) * * *$ & 18.454 & $(5.631) * * *$ \\
\hline $\mathrm{N}$ & \multicolumn{2}{|c|}{981} & \multicolumn{2}{|c|}{917} \\
\hline R-Squared & \multicolumn{2}{|c|}{0.419} & \multicolumn{2}{|c|}{0.586} \\
\hline SE Cluster & \multicolumn{2}{|c|}{ Firm } & \multicolumn{2}{|c|}{ Firm } \\
\hline
\end{tabular}

Continued 
Table 5: Continued

\section{Panel B: F-Tests of Sum of Coefficients} Require Risk Expert and Outside Chair

\begin{tabular}{lrrrrrrr} 
& Coeff & F-Stat & P & Coeff & F-Stat & P \\
\cline { 2 - 7 } $\mathrm{H}_{0}: \mathrm{RC}+$ CRISIS $* \mathrm{RC}=0$ & 1.164 & 2.98 & 0.091 & 2.520 & 25.45 & 0.001 \\
\hline
\end{tabular}

This table presents the results of a regression of TIER1 on the presence of a risk committee and control variables. RC is an indicator variable that equals 0 for all banks that do not have a risk committee in a given quarter and 1 for all matched banks that do have a risk committee in the same quarter. The sample is derived from a propensity score matching procedure which picks the best match for each $\mathrm{RC}=0$ firm in the same quarter from the $\mathrm{RC}=1$ treatment sample. Panel A presents results of the regression with coefficient estimates in columns (1) and (3) and standard errors that are clustered by firm in columns (2) and (4). Columns (1) and (2) place no restrictions on the pool of potential matches. Columns (3) and (4) require that the risk committee firm have both a risk expert and an outside director serving as chair of the committee for the firm to be included as a potential match. Panel B presents F-tests for the sum of the coefficient estimates on RC and CRISIS*RC. This sum represents the estimate of the average treatment effect on the affected firms in the crisis period. All variables are defined in Appendix A. ***,** and * indicate statistical significance at the $1 \%, 5 \%$ and $10 \%$ level, respectively. 


\section{Table 6}

The Effect of Risk Committee on Components of Tier 1 Capital Ratio for Mandatory Adopters

\begin{tabular}{|c|c|c|c|c|}
\hline \multicolumn{5}{|c|}{ Panel A: Regression Results } \\
\hline \multirow[t]{2}{*}{ Dep Var } & \multicolumn{2}{|c|}{ CAPITAL } & \multicolumn{2}{|c|}{ RWAT } \\
\hline & $\begin{array}{r}\text { Coeff } \\
(1)\end{array}$ & $\begin{array}{l}\text { SE } \\
(2)\end{array}$ & $\begin{array}{r}\text { Coeff } \\
(3)\end{array}$ & $\begin{array}{l}\text { SE } \\
(4)\end{array}$ \\
\hline $\mathrm{RC}$ & 0.013 & $(0.226)$ & 0.053 & $(0.029) *$ \\
\hline CRISIS & -0.595 & $(0.238) * *$ & 0.065 & $(0.029) * *$ \\
\hline $\mathrm{RC} * \mathrm{CRISIS}$ & 0.190 & $(0.433)$ & -0.101 & $(0.035) * * *$ \\
\hline $\mathrm{SIZE}_{\mathrm{t}-1}$ & -0.390 & $(0.131) * * *$ & 0.007 & $(0.018)$ \\
\hline IDIOVOL $_{t-1}$ & -0.004 & $(0.064)$ & 0.014 & $(0.004) * * *$ \\
\hline BETA $_{t-1}$ & 0.063 & $(0.107)$ & -0.016 & $(0.017)$ \\
\hline $\mathrm{CASH}_{\mathrm{t}-1}$ & 0.015 & $(0.018)$ & -0.007 & $(0.002) * * *$ \\
\hline TRADING $_{\mathrm{t}-1}$ & -2.712 & $(2.270)$ & -0.566 & $(0.307) *$ \\
\hline SECURITIZED $_{\mathrm{t}-1}$ & 0.945 & $(1.091)$ & 0.055 & $(0.134)$ \\
\hline $\mathrm{BTM}_{\mathrm{t}-1}$ & 4.948 & $(2.565) *$ & 0.085 & $(0.280)$ \\
\hline INSTOWN $_{\mathrm{t}-1}$ & 0.453 & $(0.450)$ & 0.058 & $(0.045)$ \\
\hline $\mathrm{LLR}_{\mathrm{t}-1}$ & 0.601 & $(0.202) * * *$ & 0.077 & $(0.044) *$ \\
\hline $\mathrm{NPL}_{\mathrm{t}-1}$ & 0.002 & $(0.067)$ & -0.028 & $(0.019)$ \\
\hline $\mathrm{ROA}_{\mathrm{t}-1}$ & 0.182 & $(0.090) * *$ & -0.013 & $(0.014)$ \\
\hline BDSIZE $_{\mathrm{t}-1}$ & -0.028 & $(0.027)$ & 0.001 & $(0.004)$ \\
\hline BDINDEP $_{\mathrm{t}-1}$ & 1.165 & $(1.515)$ & 0.521 & $(0.146) * * *$ \\
\hline $\mathrm{BDMEET}_{\mathrm{t}-1}$ & -0.050 & $(0.026) *$ & -0.005 & $(0.003) *$ \\
\hline CEOCHAIR $_{\mathrm{t}-1}$ & -0.204 & $(0.241)$ & -0.008 & $(0.025)$ \\
\hline TIME & 0.171 & $(0.063) * * *$ & -0.017 & $(0.008) * *$ \\
\hline INTERCEPT & 8.644 & $(4.263) * *$ & 0.176 & $(0.509)$ \\
\hline $\mathrm{N}$ & 98 & & 98 & \\
\hline R-Squared & 0.3 & & 0.3 & \\
\hline SE Cluster & Fir & & Fir & \\
\hline
\end{tabular}

Continued 


\section{Table 6: Continued}

\begin{tabular}{|c|c|c|c|c|c|c|}
\hline \multicolumn{7}{|c|}{ Panel B: F-Tests of Sum of Coefficients } \\
\hline \multirow[t]{2}{*}{ Dep Var } & \multicolumn{2}{|c|}{ CAPITAL } & \multirow[b]{2}{*}{$P$} & \multicolumn{3}{|c|}{ RWAT } \\
\hline & Coeff & F-Stat & & Coeff & F-Stat & $\mathrm{P}$ \\
\hline $\mathrm{H}_{0}: \mathrm{RC}+\mathrm{CRISIS} * \mathrm{RC}$ & 0.202 & 0.380 & 0.540 & -0.048 & 3.180 & 0.081 \\
\hline \multicolumn{7}{|c|}{$\begin{array}{l}\text { This table presents the results of regressions of components of Tier } 1 \text { Capital Ratio on the } \\
\text { presence of a risk committee and control variables. The dependent variables are CAPITAL which } \\
\text { is total Tier } 1 \text { capital (the numerator from TIER1) divided by total assets and RWAT which is risk } \\
\text { weighted assets (the denominator from TIER1) divided by total assets. RC is an indicator variable } \\
\text { that equals } 0 \text { for all banks that do not have a risk committee in a given quarter and } 1 \text { for all matched } \\
\text { banks that do have a risk committee in the same quarter. CRISIS is an indicator variable equal to } 1 \\
\text { for observations after the second quarter of } 2007 \text { and } 0 \text { otherwise. Observations from the year } 2007 \\
\text { are exlcluded because the exact timing of risk committee creation during } 2007 \text { is unclear for several } \\
\text { banks and the crisis began roughly halfway through the year. Panel A presents results of the } \\
\text { regressions including coefficient estimates in columns (1) and (3) and standard errors that are } \\
\text { clustered by firm in columns (2) and (4). Panel B presents F-tests for the sum of the coefficient } \\
\text { estimates on RC and CRISIS*RC. This sum represents the estimate of the average treatment effect } \\
\text { on the untreated in the crisis period. All variables are defined in Appendix A. ***, ** and * } \\
\text { indicate statistical significance at the } 1 \%, 5 \% \text { and } 10 \% \text { level, respectively. }\end{array}$} \\
\hline
\end{tabular}


Table 7

The Effect of Risk Committee on Tier 1 Capital for Voluntary Adopters (ATT)

\begin{tabular}{|c|c|c|}
\hline \multirow[t]{3}{*}{ Panel A: Regression Results } & \multicolumn{2}{|c|}{ Dep Var = TIER1 } \\
\hline & Coeff & SE \\
\hline & $(1)$ & $(2)$ \\
\hline $\mathrm{RC}$ & -0.536 & $(0.562)$ \\
\hline CRISIS & -0.650 & $(0.553)$ \\
\hline RC*CRISIS & 0.909 & $(0.544)$ \\
\hline $\mathrm{SIZE}_{\mathrm{t}-1}$ & -0.572 & $(0.233) * *$ \\
\hline IDIOVOL $_{\mathrm{t}-1}$ & -0.095 & $(0.126)$ \\
\hline BETA $_{t-1}$ & 0.077 & $(0.266)$ \\
\hline $\mathrm{CASH}_{\mathrm{t}-1}$ & 0.050 & $(0.038)$ \\
\hline TRADING $_{\mathrm{t}-1}$ & 4.605 & $(3.444)$ \\
\hline SECURITIZED $_{\mathrm{t}-1}$ & 0.836 & $(1.070)$ \\
\hline BTM $_{t-1}$ & 3.007 & (4.993) \\
\hline INSTOWN $_{\mathrm{t}-1}$ & 0.430 & $(0.959)$ \\
\hline $\mathrm{LLR}_{\mathrm{t}-1}$ & 0.579 & $(0.522)$ \\
\hline $\mathrm{NPL}_{\mathrm{t}-1}$ & -0.157 & $(0.144)$ \\
\hline $\mathrm{ROA}_{\mathrm{t}-1}$ & 0.423 & $(0.189) * *$ \\
\hline BDSIZE $_{t-1}$ & -0.028 & $(0.069)$ \\
\hline BDINDEP $_{t-1}$ & -5.534 & $(1.745) * * *$ \\
\hline BDMEET $_{\mathrm{t}-1}$ & 0.079 & $(0.049)$ \\
\hline CEOCHAIR $_{\mathrm{t}-1}$ & -0.439 & $(0.388)$ \\
\hline TIME & 0.378 & $(0.154) * *$ \\
\hline INTERCEPT & 19.667 & $(5.217) * * *$ \\
\hline $\mathrm{N}$ & 937 & \\
\hline R-square & 0.26 & \\
\hline SE Cluster & Firn & \\
\hline
\end{tabular}

Panel B: F-Tests of Sum of Coefficients

\begin{tabular}{lccc} 
& Coeff & F-Stat & P \\
\cline { 2 - 4 } $\mathrm{H}_{0}: \mathrm{RC}+$ CRISIS $* \mathrm{RC}=0$ & 0.374 & 1.11 & 0.297 \\
\hline
\end{tabular}

This table presents the results of a regression of TIER1 on the presence of a risk committee and control variables. RC is an indicator variable that equals 1 for all banks that have a risk committee in a given quarter and 0 for all matched banks that do not have a risk committee in the same quarter. The sample is derived from a propensity score matching procedure which picks the best match for each $\mathrm{RC}=1$ firm in the same quarter from the $\mathrm{RC}=0$ control sample. Panel $\mathrm{A}$ presents results of the regression with coefficient estimates in column (1) and standard errors that are clustered by firm in column (2). Panel B presents F-tests for the sum of the coefficient estimates on RC and CRISIS*RC. This sum represents the estimate of the average treatment effect on the affected firms in the cris is period. All variables are defined in Appendix A. ***,** and $*$ indicate statistical significance at the $1 \%, 5 \%$ and $10 \%$ level, respectively. 